\title{
Economic Integration and Democracy: An Empirical Investigation
}

\section{Citation}

Magistretti, Giacomo, and Marco Tabellini. "Economic Integration and Democracy: An Empirical Investigation." Harvard Business School Working Paper, No. 19-003, July 2018.

\section{Permanent link}

http://nrs.harvard.edu/urn-3:HUL.InstRepos:37326942

\section{Terms of Use}

This article was downloaded from Harvard University's DASH repository, and is made available under the terms and conditions applicable to Open Access Policy Articles, as set forth at http:// nrs.harvard.edu/urn-3:HUL.InstRepos:dash.current.terms-of-use\#OAP

\section{Share Your Story}

The Harvard community has made this article openly available.

Please share how this access benefits you. Submit a story.

\section{Accessibility}




$$
\text { H A R VAR D B US INESS S C HOOL }
$$

\section{Economic Integration and Democracy: An Empirical Investigation}

Giacomo Magistretti Marco Tabellini

Working Paper 19-003 


\title{
Economic Integration and Democracy: An Empirical Investigation
}

\author{
Giacomo Magistretti \\ Northwestern University \\ Marco Tabellini \\ Harvard Business School
}

Working Paper 19-003 


\title{
Economic Integration and Democracy:
}

\section{An Empirical Investigation*}

\author{
Giacomo Magistretti ${ }^{\dagger} \quad$ Marco Tabellini ${ }^{\ddagger}$ \\ Northwestern University MIT
}

May 24, 2017

\begin{abstract}
We study whether economic integration fosters the process of democratization and the channels through which this might happen. Our analysis is based on a large panel dataset of countries between 1950 and 2014. We instrument actual trade with predicted trade constructed by estimating a time-varying gravity equation similar to Feyrer (2009). We find that economic integration has a positive effect on democracy, driven by trade with democratic partners and stronger for countries with lower initial levels of economic and institutional development. These results are consistent with a learning/cultural exchange process whereby economic integration promotes the spread of democracy from more to less democratic countries. We corroborate this interpretation by providing evidence against alternative mechanisms, such as income effects, human capital accumulation, and trade-induced changes in inequality.
\end{abstract}

Keywords: democracy, institutional development, economic integration, international trade.

JEL Classification: F14, F15, P16.

\footnotetext{
*We thank Daron Acemoglu, Alberto Alesina, Nicola Gennaioli, and Martí Mestieri for their many and very useful comments. Special thanks also to Arnaud Costinot, Francesco Giavazzi, Benjamin Marx, Luigi Pascali, and Nico Voigtlaender for their insightful advice. All remaining errors are ours.

${ }^{\dagger}$ Northwestern University, Department of Economics, 2001 Sheridan Road, Evanston, IL, 60208-2600, USA; giacomo.magistretti@u.northwestern.edu.

${ }^{\ddagger}$ MIT, Department of Economics, 77 Massachusetts Avenue, E19-750, Cambridge, MA, 02142-1347, USA; mtabe@mit.edu.
} 


\section{Introduction}

Over the last 60 years, the world has become substantially more integrated while, at the same time, several non-democratic countries have embarked upon a process of democratization. Are these phenomena related? Can trade and, more generally, economic integration foster democracy and favour institutional change? Economists have long been interested in these questions, but the existing empirical evidence is at best mixed. ${ }^{1}$ Indeed, a sounder understanding of the relationship between economic integration and democracy is important not only in its own right, but also in light of the recent literature documenting a positive effect of democratic institutions on growth (e.g. Rodrik and Wacziarg, 2005; Papaioannou and Siourounis, 2008; Acemoglu et al., 2015): if economic openness promotes democratization, the former can benefit countries not only directly, through the standard "gains from trade", but also indirectly, by favouring the emergence of growth-enhancing institutions.

Studying the relationship between economic integration and institutions is particularly complicated not only because of several econometric difficulties, but also owing to the lack of unambiguous theoretical predictions. For instance, trade can generate a redistribution of resources and alter the political equilibrium, but the direction of this change may depend on the identity of the groups that benefit from trade, and/or on the pre-existing economic and institutional environment (see Acemoglu et al., 2005 and Puga and Trefler, 2014). Moreover, when the institutions of trade partners are sufficiently similar, trade may induce countries to engage in a "race to the top" to appropriate the gains from specialization in institutionally intensive goods (see Levchenko, 2007). ${ }^{2}$

Since the seminal work by Grossman and Helpman (1991), another robust finding in the literature is that the trade-induced spread of ideas can foster economic growth. ${ }^{3}$ However, there has not been a systematic analysis of whether economic integration can also favour a process of cultural transmission that promotes institutional change. A related question

\footnotetext{
${ }^{1}$ For instance, Rigobon and Rodrik (2005) find a negative relationship between trade openness and democracy, whereas López-Córdova and Meissner (2008) estimate a positive and sizeable one.

${ }^{2}$ For the role that institutions play in shaping the pattern of comparative advantage (and thus of trade) across countries, see, among others, Nunn (2007) and Costinot (2009).

${ }^{3}$ See, for instance, the recent works by Alvarez et al. (2013) and Sampson (2016). Grossman and Helpman (2015) present a more complete discussion on this topic.
} 
is whether learning (if any) occurs faster for countries with weaker initial institutions that are further away from a sort of "Democratic Frontier". On the one hand, countries where institutions are less developed may have more to learn from their (democratic) partners. On the other hand, however, the ruling elites in these countries may be in a better position to resist the pressure of the citizens, and it may thus take longer for democracy to emerge.

In our paper, we study empirically if, and through which channels, economic integration fosters democracy, by using a large panel dataset of countries over the period 1950-2014. To address endogeneity concerns, we rely on an instrumental variable (IV) approach that, as in Feyrer (2009), exploits the rise in the importance of air, relative to sea, transportation over the last 60 years (see Hummels, 2007). In particular, actual trade is instrumented with predicted trade obtained from a time-varying gravity equation estimated by modelling the bilateral resistance term as a function of both sea and air distances between countries, and allowing the elasticity of trade with respect to such distances to change over time. ${ }^{4}$ The time-varying nature of the resulting IV allows to control for year and country fixed effects in the regression of interest, strengthening the causal interpretation advanced in our work.

We find that economic integration has a positive and significant impact on democracy. This effect is driven by trade with democratic partners, and accumulates over time. We test the robustness of our results by using alternative specifications and by performing a number of checks to mitigate concerns that our instrument is capturing common trends of less developed countries towards democratization. Moreover, to deal with the highly persistent nature of institutions, we repeat the analysis using a dynamic panel model.

Next, we investigate the channels through which economic integration can affect the democratization process. Our evidence paints a picture consistent with a cultural exchange/learning channel whereby economic openness promotes democracy through the spread of ideas from more to less democratic countries. Our interpretation is that, through economic integration, citizens of autocratic countries get to know democracy and, more broadly, the institutions of their partners. As a result, demand for more inclusive institutions increases,

\footnotetext{
${ }^{4}$ Feyrer (2009) uses this approach to investigate the effect of trade on growth, while we study the relationship between economic integration and democracy.
} 
inducing ruling groups to extend franchise. ${ }^{5}$

We corroborate this interpretation in two ways. First, we provide evidence against alternative mechanisms, such as income effects, human capital acquisition, and trade-induced changes in inequality. Second, we show that the positive effect of economic integration on democracy is stronger for countries with lower levels of infrastructural development and institutional quality at baseline. These findings are supportive of the learning channel mentioned above: over the last 60 years, (former) peripheral countries and emerging markets have become much more integrated to the rest of the world. At the same time, the learning process is arguably stronger for those countries where the institutional set up is weaker, as they have more room to learn from their democratic partners.

Our results speak to several strands of the literature. First, they are related both to the emerging literature on the relationship between culture and institutions (see Alesina and Giuliano, 2015, for a review) and to the literature on institutional change and regime switch (see, among others, Acemoglu and Robinson, 2006). Second, our findings are consistent with works that emphasise the importance of learning for policy adoption (see, among others, Buera et al., 2011) and for growth (e.g. Alvarez et al., 2013; Sampson, 2016). We contribute to this literature by showing that learning may involve institutions, and not only policies, and by presenting suggestive evidence that trade can be a mediating factor that favours cultural transmission. ${ }^{6}$

Third, our results complement the works by Nunn (2007) and Costinot (2009) by showing that not only institutions shape the pattern of international trade by providing a source of comparative advantage, but also trade itself can promote institutional change, as discussed in Levchenko (2007). ${ }^{7}$ While the positive effect of economic openness on democracy is consistent with findings in López-Córdova and Meissner (2008), we improve upon their analysis in at

\footnotetext{
${ }^{5}$ An alternative hypothesis could be that elites of autocratic countries learn from their partners and spontaneously change institutions. We are less inclined to believe in this view of efficient institutions.

${ }^{6}$ In this respect, we also complement Guiso et al. (2009) by showing that, besides the impact that cultural distance can have on the propensity of countries to trade with each other, trade itself can favour the process of cultural exchange.

${ }^{7}$ More precisely, in Levchenko (2007) trade favours institutional development by inducing countries to engage in a "race to the top", in order to improve their domestic institutions. Instead, our findings suggest that institutions can improve (also) as a result of cross-country learning.
} 
least two ways. On the one hand, differently from their repeated cross-sections, we estimate panel data models that systematically control for country fixed effects. ${ }^{8}$ On the other, we show that economic integration can have substantially different effects on the process of democratization according to the institutions of trade partners, and we provide evidence for (or against) mechanisms that can be driving these findings.

Finally, our paper is related to the vast literature on institutions and economic prosperity. The recent work by Acemoglu et al. (2015) shows that democracy has a strong, positive effect on growth. ${ }^{9}$ If that is the case, our findings suggest that the economic gains from trade can be greatly amplified by the emergence of welfare enhancing institutions induced by economic integration.

Our work is organised as follows. Section 2 describes the construction of the IV, lays out our empirical strategy, and presents the data used in this paper. In Section 3, we report our main results on the positive effect of economic integration on democracy, and show that the latter is driven by trade with democratic partners. In this section, we also perform several robustness checks and repeat our analysis using a dynamic panel model. Section 4 discusses mechanisms through which economic integration can affect democratization, and provides suggestive evidence against alternative explanations and in favour of a learning/cultural transmission channel. Section 5 concludes.

\section{Empirical Strategy}

Empirically identifying the causal effect of economic integration on institutions is particularly difficult, because of both omitted variable bias and reverse causation issues. On the one hand, richer countries trade more and are also more likely to be democratic. On the other, as shown in Nunn (2007) and Costinot (2009), institutions are themselves important determinants of trade. Related to this, Giuliano et al. (2013) find that democracy has a positive effect on the

\footnotetext{
${ }^{8}$ The different source of variation exploited by our instrument allows us to do so. See Section 2.1.

${ }^{9}$ This result is consistent with Rodrik and Wacziarg (2005), Persson and Tabellini (2008, 2009), and Papaioannou and Siourounis (2008). It should be noted, however, that there is no universal consensus on the idea that democracy causes growth. In fact, other authors have suggested that human capital and income accumulation are key drivers of well-functioning democracies (e.g. Glaeser et al., 2007).
} 
introduction of economic reforms, including trade liberalizations. Similarly, economic and political liberalizations often occur simultaneously, and it is thus hard to identify the effects of economic openness on political outcomes (see Giavazzi and Tabellini, 2005).

One way to overcome endogeneity issues is to exploit exogenous variation induced by historical events, as in Acemoglu et al. (2005) and Puga and Trefler (2014). However, the number of episodes that can be used to estimate the causal effect of trade on democracy is limited. Moreover, at the time most of them occurred, only a small fraction of the world was democratic, and few countries had modern institutions in place. For this reason, historical episodes may fail to identify the trade-induced process of democratization resulting from gradual cross-country learning. Motivated by this discussion, rather than relying on historical sources of variation, we investigate the relationship between trade and democracy using an IV approach that we now describe.

\subsection{Construction of the Instrument}

Hummels (2007) shows that, over the last 60 years, technological change and the advent of air transportation have substantially altered the structure of international trade. In particular, the importance of air, relative to sea, transportation has increased dramatically. Moreover, as discussed also in Feyrer (2009), technological improvements in international transportation are shared worldwide and are arguably exogenous to the evolution of the economic and political environment of any individual country. At the same time, they affect different country-pairs differently, according to their geographic location: for instance, a relative improvement in air vis à vis sea transportation should result in a larger increase in trade flows between Japan and France than between Japan and China. This provides us with an arguably exogenous source of variation over time at the country-pair level, which we are going to exploit. ${ }^{10}$

Consistently with the aforementioned idea, we estimate a gravity equation that includes both air and sea distance between each country-pair, as in Feyrer (2009). By allowing the elasticity of trade with respect to these two distances to change over time, we capture the

\footnotetext{
${ }^{10}$ See Feyrer (2009) for a more detailed discussion on this source of variation and its exogeneity.
} 
evolution of their relative importance for bilateral trade between any two countries. A similar approach, even though in a different context, is also used in Pascali (forthcoming), who takes advantage of the fact that the introduction of the steamship in the 1870s differently affected the time and the costs of different routes (previously determined by wind patterns). Relative to the previous literature (e.g. Frankel and Romer, 1999), these strategies allow to construct a time-varying instrument that, in turn, makes it possible to control for time and country fixed effects in our regression of interest, strengthening any causality argument based on cross-country, panel analyses.

As in the first two aforementioned papers, we estimate bilateral trade flows starting from a gravity equation based on Anderson and Van Wincoop (2003). Importantly, we are not interested in identifying the causal effect of distance on trade, but rather to capture the change in the correlation between the latter and two different distances (i.e. sea and air) over time. For this reason, the exact specification we estimate differs from the canonical gravity model proposed by Anderson and Van Wincoop (2003).

Following Feyrer (2009), we model the bilateral resistance term, $\tau_{i j t}$, as a function of sea and air distances. In particular, we assume the following functional form for $\tau_{i j t}:{ }^{11}$

$$
\ln \left(\tau_{i j t}\right)=\beta_{q}^{\text {sea }} \ln \left(\text { seadist }_{i j}\right)+\beta_{q}^{\text {air }} \ln \left(\text { airdist }_{i j}\right)
$$

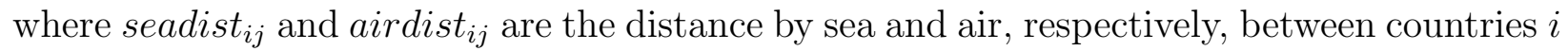
and $j$. Importantly, coefficients on distances in expression (1) are allowed to vary across timeperiods $q$, capturing the differential effect over time of technological change in air relative to sea transportation discussed above. We allow $q$ to have a frequency lower than $t$, since improvements in technology may take time to be developed and introduced.

The exact specification of the gravity equation used to predict bilateral trade flows between countries $i$ and $j$ at time $t$ is:

$$
\ln \left(\text { trade }_{i j t}\right)=\chi_{i j}+\varphi_{i t}+\psi_{j t}+\beta_{q}^{s e a} \ln \left(\text { seadist }_{i j}\right)+\beta_{q}^{a i r} \ln \left(\text { airdist }_{i j}\right)+u_{i j t} .
$$

\footnotetext{
${ }^{11}$ The same assumption is made also in Pascali (forthcoming), even though with respect to sail versus steamship distances, rather than sea versus air.
} 
A few remarks are in order. First, consistently with Feyrer (2009) and Pascali (forthcoming), coefficients for air and sea distance are allowed to vary at 5-year intervals $q$. Second, the pair fixed effects $\chi_{i j}$ control for bilateral (time invariant) characteristics between countries $i$ and $j$, such as common language, colonial relationship, and common border, which have been shown to be important in predicting bilateral trade flows. ${ }^{12}$

Third, we include country-year fixed effects $\varphi_{i t}$ and $\psi_{j t}$ in (2) and (3). We do so for two reasons. On the one hand, this is consistent with the gravity equation specification of Anderson and Van Wincoop (2003), which includes country-time determinants of bilateral trade (notably, measures of countries' economic size). On the other hand, $\varphi_{i t}$ and $\psi_{j t}$ absorb any country-time specific variation that may affect bilateral trade and confound the effect of geographic distance. ${ }^{13}$ Indeed, the exogenous variation we want to capture works at the pair-time level (Japan-France versus Japan-China in our previous example), going above and beyond any country-time level effect (say, any Japan-specific change occurring during our sample period with an effect on trade and correlated with transportation technological change). ${ }^{14}$ In this respect, we improve upon Feyrer (2009), who does not control for these fixed effects, and Pascali (forthcoming), who presents results for a gravity specification with country-year fixed effects only as a robustness check, but then does not use them to construct his instrumental variables.

Our instrument, i.e. predicted trade for each country $i$ at time $t$, is obtained by taking the exponential of predicted bilateral log trade flows from (2), and summing these over all

\footnotetext{
${ }^{12} \mathrm{As}$ a robustness check, we also derive our instrument from a specification of (2) that replaces $\chi_{i j}$ with a vector $x_{i j}$ including those three variables, namely

$$
\ln \left(\text { trade }_{i j t}\right)=\varphi_{i t}+\psi_{j t}+\beta_{q}^{s e a} \ln \left(\text { seadist }_{i j}\right)+\beta_{q}^{\text {air }} \ln \left(\text { airdist }_{i j}\right)+x_{i j}^{\prime} \phi+v_{i j t} .
$$

Our main results are unaffected, as shown in Table A4.

${ }^{13}$ For instance, the usual measures of country size included in gravity equations (e.g. GDP or population) or any other time-varying, country-specific characteristic with an impact on trade flows and correlated with the adoption and use of new transportation technologies.

${ }^{14}$ Controlling for this battery of fixed effects is consistent with the suggestions in Baldwin and Taglioni (2007) and Head and Mayer (2014). We follow Baldwin and Taglioni (2007) also in computing $\log \left(\right.$ trade $\left._{i j t}\right)$ as the mean of the log of the two flows between $i$ and $j$ (instead of the $\log$ of the mean), and by leaving trade in current $\$$ US, while controlling for time fixed-effects (instead of deflating by the US CPI, as it is common). Note that the time fixed-effects are absorbed by $\varphi_{i t}$ and $\psi_{j t}$.
} 
partners $j \neq i$. In formulas:

$$
\begin{aligned}
{\widehat{\text { trade }_{i t}}} & =\sum_{j \neq i} \omega_{i j} \exp \left(\ln {\widehat{\text { trade }_{i j t}}}\right) \\
& =\sum_{j \neq i} \omega_{i j}\left[e^{\hat{\beta}_{q}^{\text {sea }}\left(\ln \text { seadist }_{i j}\right)+\hat{\beta}_{q}^{a i r}\left(\ln \text { airdist }_{i j}\right)}\right]
\end{aligned}
$$

Differently from Feyrer (2009), and consistently with Pascali (forthcoming), we do not include the estimated fixed effects in predicted bilateral trade, so as to increase our confidence that the instrument is indeed capturing only the change in the importance of air relative to sea transportation, i.e. the desired exogenous source of variation.

As it is common in the literature, observations are weighted in order to improve the precision of the instrument. Specifically, $\omega_{i j}$ is the time average of bilateral trade shares between countries $i$ and $j$. Importantly, our main results are robust to constructing the instrument without any weights (see Table 3, column 4).

Finally, note that we implement the procedure described above in order to obtain a country-specific, time varying IV for trade that is arguably exogenous to the economic and political environment of each individual country. It is not the first stage of the two stages least squares (2SLS) estimation method adopted throughout our paper.

\subsubsection{Instrument Validity and the Exclusion Restriction}

The idea of instrumenting actual trade with predicted trade derived from a gravity equation goes back at least to Frankel and Romer (1999), who used it in a cross-sectional study of the effect of trade on income. Other scholars have tried to make this strategy dynamic, either by re-estimating the gravity equation at different points in time (e.g. López-Córdova and Meissner, 2008), or by pooling data for different years and including the estimated timeeffects and time-varying regressors in the construction of the IV, so as to obtain variation over time (e.g. Alesina et al., 2016). However, a measure of predicted trade derived from a single distance (e.g. great circles) and non-geographic variables may be confounded by factors that are not entirely exogenous to the outcomes of interest. In this respect, our strategy improves upon previous works by constructing predicted trade relying only on the 
desired source of variation, as in Pascali (forthcoming).

As discussed above, our measure of predicted trade exploits variation that is arguably exogenous to any single country. Also, throughout our work, we show that the instrument is reasonably strong. However, some concerns remain that our IV may not be completely excludable from a regression of democracy on trade (equation (5) below). Specifically, our instrument may be capturing not only the effect of trade (in goods) per se, but also that of migration flows, FDIs, and ideas. Indeed, with the improvements in air transportation, not only goods, but also people and ideas are transferred more easily from one country to another, and these may, in turn, affect democracy and institutions. For this reason, throughout our work we interpret our results as the effect of economic integration/globalization on democracy, and not only that of, strictly speaking, trade. Yet, FDIs, migration, and flows of ideas can also be considered "trade", to some extent. Thus, whenever we use the word trade in talking about our findings, we always refer to this broader definition.

\subsection{Relation Between Economic Integration and Democracy}

The measure of predicted trade constructed above is used as an instrument for actual trade when estimating the following expression:

$$
\text { democracy }_{i t}=\gamma_{i}+\lambda_{t}+\beta \log \left(\text { integration }_{i t}\right)+x_{i t}^{\prime} \delta+\varepsilon_{i t}
$$

where democracy it $_{\text {is }}$ the 21-level Polity2 democracy score from the Polity IV project, integration $_{i t}$ is measured as the ratio of trade over GDP (in country $i$ at time $t$ ), $\gamma_{i}$ and $\lambda_{t}$ are country and time fixed effects, and $x_{i t}$ is a vector of time varying controls that we include in some specifications (see Section 2.3 for the precise definition of our variables and Section 3 for details on the controls). ${ }^{15}$

Due to the highly persistent nature of democracy, and in order to account for the gradual diffusion of new transportation technologies (the key source of variation behind our IV), all

\footnotetext{
${ }^{15}$ Trade is divided by GDP in order to better appreciate the "trade intensity" and, ultimately, the level of economic integration of a country, with respect to its "economic size". We acknowledge that GDP might be endogenous, and it is probably itself influenced by trade. For this reason, we also estimated (5) and (6) dividing trade by GDP lagged 5 years. Results remained consistent.
} 
equations are estimated using data at 5 -year intervals. ${ }^{16}$ To assess the robustness of our results, we also repeat the analysis including lags for democracy on the right hand side in a dynamic panel model (see Section 3.4).

To provide evidence for our main result, i.e. that what matters for democratization is integration with democratic partners, we estimate a version of (5) that allows integration with democratic and non-democratic partners to have a differential effect on democracy, namely:

$$
\text { democracy }_{i t}=\gamma_{i}+\lambda_{t}+\beta^{\text {demo }} \log \left(\text { integr }_{i t}^{\text {demo }}\right)+\beta^{\text {auto }} \log \left(\text { integr }_{i t}^{\text {auto }}\right)+x_{i t}^{\prime} \delta+\varepsilon_{i t}
$$

where $i n t e g r_{i t}^{g}$ refers to trade (scaled by GDP) conducted by country $i$ with partners with institutional regime $g$ at time $t$. If economic openness fosters a process of cultural transmission and institutional learning, the coefficient on integration with democracies, $\beta^{\text {demo }}$, should be positive and significant, while that on integration with autocracies, $\beta^{\text {auto }}$, should be insignificant (and/or negative). Note that there are two endogenous regressors in expression (6), i.e. integr ${ }_{i t}^{\text {demo }}$ and integr ${ }_{i t}^{\text {auto }}$. We instrument them by using two different IVs, constructed as in Section 2.1, with the only difference that the summation in (4) is conducted separately for democratic and non-democratic partners.

When estimating (6), we expose ourselves to the Manski reflection problem, since the choice of trade partners is likely endogenous in our setting. As a matter of fact, it is possible that countries start to trade more with democracies precisely when becoming more democratic. Specifically, expression (6) may suffer from endogeneity from two separate sources: the actual amount of trade flows, and the choice of trade partners. While our measure of predicted trade deals with the first, it does not address the second. In order to mitigate the latter concern, in constructing our instrument, we define as democratic (resp. autocratic) those partners that were democratic (resp. autocratic) 5 years before. All other remaining concerns related to our estimation strategy, and the way in which we deal with them, are discussed when presenting our results.

\footnotetext{
${ }^{16}$ As in Acemoglu et al. (2008), rather than averaging the data over 5-year periods, we prefer to use observations every 5 years, from 1950 to 2010, in order to reduce concerns related to serial correlation.
} 


\subsection{Data}

Our final dataset is an unbalanced panel of 116 countries over the time span 1950-2014. Details on variable sources and definitions can be found in Table A1. Summary statistics for the most important variables are presented in Table 1 . In addition, we report the exact list of country-periods used in our analysis in Table A7. In this subsection, we briefly describe only our main variables of interest.

We measure democracy with the Polity2 score calculated within the Polity IV project. This variable takes on integer values between -10 (full autocracy) and 10 (full democracy). In Table 3, we test the robustness of our main results using a dichotomous $0-1$ version of Polity2, namely dpolity $\equiv \mathbb{1}($ Polity2 $>0)$, and another dummy variable constructed from Freedom House data, namely demo_f $\equiv \mathbb{1}$ (Freedom Rating $\geq 4) .{ }^{17}$

Bilateral trade flows are obtained from the IMF Direction of Trade Statistics. For each exporter-importer pair, in each year, there are potentially four measures of trade, namely exports and imports reported by both countries. To estimate the gravity equation and derive total trade of country $i$ at time $t$, we follow the literature in considering the average of these four (see Table A1 for details).

Air distance between each pair of countries is based on the great circle distances between the most important cities in a country reported in the CEPII dataset (see Mayer and Zignago, 2011). This same source also provides data on whether any two countries: $i$ ) share a common border; ii) speak a common language; and iii) have ever been or currently are in a colonial relationship. These variables are included in the gravity specification (3).

Sea distances were calculated by first identifying the main commercial port for each country, and then collecting data on the sea-routes between ports of each pair of countries from the website vesseldistance.org. ${ }^{18}$ As in Feyrer (2009), landlocked countries are excluded from our analysis, as the construction of the sea distance was not possible for them.

\footnotetext{
${ }^{17}$ Freedom Rating is the mean of the variables Political Rights and Civil Liberty, both measured on a 1-7 scale, with 7 corresponding to highest level of freedom.

${ }^{18}$ Given the particular geography of the US and Canada, we computed the sea distance between these two countries and the rest of the world as the shortest sea-route from the main port on either the East or the West coast. A similar strategy is used for Russia, in this case considering three ports (on the Baltic sea, Black Sea, and Pacific Ocean).
} 
GDP and population data come from the Penn World Table, version 9.0. In Section 4, we also use data on human capital from Barro and Lee (2013), the number of telephone lines per 100 people from the World Bank (World Development Indicators), the index of ethnic polarization from Montalvo and Reynal-Querol (2005), and the presence of state religion from Barro and McCleary (2005). Finally, in some regressions, we use data on the number of minerals from Parker (1997) and on sector-specific value added from the World Bank.

\section{Main Results}

We now turn to the description of our results. Section 3.1 presents the estimates of the gravity equation. Next, we study the relationship between economic integration and democracy in Section 3.2, and perform a number of robustness checks in Section 3.3. Finally, in Section 3.4, we show a dynamic panel version of our results.

\subsection{Gravity Step}

Figure 1 and column 1 in Table A2 report the estimated coefficients for the gravity equation (2). They show that the importance of air distance has increased throughout our sample period: the elasticity of bilateral trade flows to air distance has grown more and more negative over time, ceteris paribus. On the contrary, the estimated elasticity of trade to sea distance has remained fairly stable over the last 60 years. A similar pattern, especially for air distance, emerges also from Figure A1 and column 2 of Table A2, which present results for specification $(3){ }^{19}$

These trends are consistent with findings in Hummels (2007), who shows that the cost of air transportation fell dramatically between the mid 1950s and the mid 1970s because of technological progress (notably, the diffusion of the jet engine), and kept declining at a slower pace afterwards. At the same time, Hummels presents evidence that the reduction in ocean shipping costs was not as pronounced as the decline in air freight. This provides support to Feyrer's (and our) IV strategy.

\footnotetext{
${ }^{19}$ Air and sea coefficients for specification (2) should be interpreted as changes relative to those estimated for 1950, which are dropped to avoid perfect multicollinearity. This drop is instead not needed in (3).
} 


\subsection{Economic Integration and Democracy}

We first study the effect of economic integration on democracy by estimating equation (5). Results are reported in columns 1 and 2 of Table 2. Both OLS and 2SLS coefficients (columns 1 and 2 of Panel A, respectively) are positive, with the latter larger in magnitude but less precisely estimated. ${ }^{20}$ Unless differently specified, standard errors throughout the paper are adjusted to take into account the fact that the IVs themselves have been estimated. ${ }^{21}$ While these findings may suggest a positive and significant homogeneous relationship between integration and democracy, their statistical significance is not stable across various specifications and checks, including the reduced form coefficient in column 1 of Table A3. Several explanations exist for this lack of robustness. On the one hand, it is consistent with the ambiguous theoretical predictions discussed in the introduction. On the other, it may arise because economic integration has heterogeneous effects on democracy, depending on the institutions of trade partners.

In what follows, we focus our attention on the second possibility and estimate equation (6), where we allow economic integration with democratic and non-democratic partners to have different effects on institutional change. Results for our preferred specification are reported in columns 3 and 4 of Table 2 (Panel A), for OLS and 2SLS respectively. The corresponding first stage estimates are shown separately for each endogenous regressor in Panels C and D, and depicted graphically in Figure 2. At the bottom of each first stage panel, we report Angrist and Pischke (AP) F-statistics to separately test the strength of each IV. The Kleibergen-Paap (KP) statistics is presented in the last row of Panel A, to jointly test for weak IVs. ${ }^{22}$ In all cases, the evidence provided by the aforementioned statistics suggests that predicted trade with democracies and autocracies is strongly correlated with

\footnotetext{
${ }^{20}$ First stage results (reported in Panel B, column 2) and the F-stat for weak instruments (bottom row of Panel A) suggest that the instrument is strong.

${ }^{21}$ In particular, we follow the numerical strategy detailed in footnote 15 in Frankel and Romer (1999) and in footnote 15 in Pascali (forthcoming).

${ }^{22}$ Since critical values for the KP statistics have not been tabulated, Bazzi and Clemens (2013) suggest to report KP together with Cragg-Donald (CD) statistics (which refer to the case of iid errors), and compare both to the critical values of the latter, reported in Stock and Yogo (2005). For column 4 of Table 2, the CD statistics is 52.3 and the critical value for a $5 \%$ test with maximal size of $15 \%$ for our case of two endogenous variables and two IVs is 4.58 , hence way smaller than all our F-statistics.
} 
its actual trade counterpart.

2SLS estimates in Panel A, column 4, show that economic integration with democratic partners has a positive and significant effect on democracy, while the impact of economic integration with autocracies is not statistically different from zero. The point estimate of 3.414 for $\beta^{\text {demo }}$ implies that, if a country doubles its trade over GDP with democratic partners over a 5-year period, its Polity2 score is predicted to increase by about 3 points, ceteris paribus. As a matter of comparison, this amounts to the difference in the 2014's score of Tunisia with respect to Western European countries. Considering that the level of integration with democracies more than doubled at least once for about a quarter of the countries in our samples (e.g. Mozambique between 1985 and 1990; Poland between 1970 and 1975; South Korea between 1960 and 1965), the implied magnitudes of estimates in column 4 are economically significant. Moreover, as shown in Section 3.4, this effect tends to accumulate over time, becoming substantially larger in the long run. 2SLS results are further corroborated by reduce-form estimates, reported in Table A3 (column 2) and in Figure 3.

\subsubsection{OLS versus IV: Investigating the Validity of the Instrument}

2SLS estimates in Table 2 are about two times larger than their corresponding OLS. While the first stage and F-statistics reassure us about the strength of our IVs, concerns may arise on their validity and, in particular, on the exclusion restriction. Specifically, it is hard to attribute the difference mentioned above only to OLS bias since, if anything, one would expect OLS to be upward, and not downward biased. ${ }^{23}$

One possible explanation for the discrepancy we find is the presence of measurement error in trade data, that may lead to attenuation bias of OLS coefficients. A second possibility is that, as already discussed in Section 2.1.1, our instrument may not be identifying the effect of trade in goods per se but, more broadly, that of economic integration and globalization. Both explanations seem compelling, and none of them would threaten the validity of our estimates.

\footnotetext{
${ }^{23}$ The existing evidence (e.g Giavazzi and Tabellini, 2005) shows that political liberalizations are often conducive to economic liberalizations. Also, findings in Levchenko (2007), Nunn (2007), and Costinot (2009) suggest that, if anything, OLS estimates should be upward biased.
} 
However, there exist other, possibly more problematic, reasons for the gap between OLS and 2SLS estimates documented in Table 2. First, there is evidence that democratization waves (e.g. the Arab Spring) often affect several countries in a certain area simultaneously and rather independently from their specific economic conditions (see the discussion in Acemoglu et al., 2015). Since predicted trade is a function of the distance between countries, our instrument may confound the effect of economic integration with that of these waves.

To deal with this issue, in column 5 of Table 2, we control for demo_wave, the share of democracies in each country's "influence set". This variable is constructed following Acemoglu et al. (2015), who use it to operationalise the concept of democratization waves (see their paper for more details). In a nutshell, the world is first divided in six geographic regions. Then, within those regions, countries are split in two subgroups, according to their initial institutions (democracy if Polity2 $>0$, autocracy if Polity2 $\leq 0$ ). Each country is assumed to be (potentially) affected by democratizations occurring only within its "influence set" $S_{i}$, made up of countries: $i$ ) in its region and $i i$ ) with its same initial institutions (excluding country $i$ itself). Our control is obtained as

$$
\text { demo_wave }_{i t}=\frac{1}{\left|S_{i}\right|} \sum_{j \in S_{i}} d_{p o l i t y} \text { jt }_{1}
$$

where dpolity $_{j t}$ is a dichotomous version of Polity2 (see Section 2.3). ${ }^{24}$ Notably, we are not interested in estimating the causal effect of demo_wave, as the "Manski reflection problem" prevents us from doing so (see Angrist, 2014). Yet, controlling for demo_wave is an indirect way to check whether the exclusion restriction is violated, and our IVs are picking up (at least in part) variation unrelated to economic integration. As one can see from column 5 , results are fully robust to the inclusion of this control. First stages (column 5 in Panels $\mathrm{C}$ and D in Table 2) and reduced form estimates (column 3 in Table A3) are also virtually unaltered.

A second concern, related to the previous one, is that our estimates may be capturing trends specific to some groups of countries that have simultaneously become more integrated

\footnotetext{
${ }^{24}$ To mitigate endogeneity concerns, throughout the paper we use a version of demo_wave where the summation in (7) is done over dpolity lagged one year. Results are robust to the contemporaneous measure or the 5-year lag, and to the use of the absolute number instead of the share.
} 
and more democratic, for reasons other than trade with democracies. We try to address this concern by separately including an interaction between year dummies and dummies for being: i) a non-OECD country; and ii) non-democratic at baseline. ${ }^{25}$ Results for these exercises are reported in columns 6 and 7 of Table 2 , respectively. While the magnitude of $\hat{\beta}^{\text {demo }}$ is somewhat smaller, especially in column 7 , the effect of economic integration with democracies is positive and significant, as in our baseline specification (column 4). Again, first stages and reduced form estimates are essentially unchanged.

\subsection{Robustness}

We test the robustness of our findings in a number of ways, reporting results in Table 3. Column 1 reproduces our baseline specification (column 4 of Table 2), to ease comparisons. As a first check, we explore whether our estimates are unduly affected by outliers. In particular, we replicate the analysis in column 1 after removing from the sample all the observations with a standardised residual in the baseline regression that is larger than 1.96 in absolute value. Column 2 shows that, if anything, the coefficient on integration with democracies becomes larger and more precisely estimated, while that for integration with autocracies remains small and not different from zero.

Another concern is that the positive effect we estimate is driven by the peculiar democratization process experienced by Soviet countries in the early 1990's, after the dissolution of the Soviet Union. To address that, in column 3, we exclude the ex-USSR countries that are present in our sample: results are basically unaltered.

Next, column 4 reports results for a version of our instrument obtained without weighting bilateral predicted trade (see equation (4) and the discussion that follows it). Again, results remain very similar to those in column 1 . The coefficient on integration with democracies is slightly larger and still significant at the $5 \%$ level, while that on integration with autocracies is not significant. As expected, F-statistics are somewhat lower for this specification, but they still remain above conventional critical values.

The last two columns of Table 3 present checks with respect to our measure of democracy.

\footnotetext{
${ }^{25}$ See also the robustness results to the exclusion of ex-USSR countries that we report in Table 3.
} 
In column 5, we estimate a linear probability model where the dependent variable is dpolity, a dichotomous version of Polity2 described in Section 2.3. The rationale of this exercise is to probe the robustness of our results to the use of a variable that does not capture small changes in Polity2, which can be quite nosily measured. Estimates, reported in column 5, show that our results are not affected by the use of this alternative measure. ${ }^{26}$

Finally, we check that our results are robust to the use of sources for the democracy measure other than the Polity IV project. In particular, column 6 reports results obtained using demo_fh, a dummy variable for democracy constructed using data from Freedom House, the other most commonly used data source for democracy measures in the literature (see Section 2.3 for its precise definition). Also in this case, results remain very similar to the ones in column 5 and consistent with the ones in column 1.

As a further robustness exercise, we replicate Table 2 using an IV based on the alternative gravity specification presented in equation (3). Results are reported in Table A4. ${ }^{27}$ The positive impact of integration with democracies on democratization is virtually unchanged in our baseline specification (column 4), and just slightly less significant in columns 5 to 7. The coefficient on integration with autocracy is not statistically different from zero in any 2SLS estimation.

As a last check, we tried to estimate the gravity equation relying on the Poisson Pseudo Maximum Likelihood (PPML) estimator suggested by Santos Silva and Tenreyro (2006). However, the very high number of fixed effects in both specifications (2) and (3) prevented us from obtaining convergence of the maximization algorithm. As a workaround, we decided to reduce the dimensionality of the problem and estimate simplified versions of (2) and (3) that include a lower number of fixed effects. ${ }^{28}$

By simplifying the gravity equation as discussed above, we were able to obtain convergence for the PPML estimators. Table A5 compares results obtained using the PPML and

\footnotetext{
${ }^{26}$ When interpreting the magnitude of coefficients in columns 5 and 6 , it should be kept in mind that the scale of the dependent variable is different from the one of Polity2.

${ }^{27}$ The different number of observations in this sample, compared to the one of Table 2 , is due to the fact that we do not need to drop the baseline period for perfect collinearity. See footnote 19.

${ }^{28}$ In particular, the simplified version of (2) includes distances and fixed effects for country-pair and time. The one for (3) includes distances, the same three country-pair specific variables, and fixed effects for origin, destination, and time.
} 
the corresponding OLS version of the IVs. Even though we do not want to over-emphasise these findings (since they are obtained from less theoretically sound gravity specifications), a reassuring picture emerges. When comparing columns 2 and 3, and columns 5 and 6 , results appear to be fairly consistent: if anything, the effect of integration with democracies is larger and more precisely estimated when using the PPML-based IVs instead of the OLSbased ones. ${ }^{29}$ Instead, results for the effect of economic integration with autocracies are not sensitive to the strategy used to estimate the gravity equation.

\subsection{Dynamic Panel Model}

To address possible issues related to the highly persistent nature of institutions, we now turn to a dynamic panel model that includes (at least) one lag of the democracy score as an additional regressor in (5) and (6). The specification for total trade becomes:

$$
\operatorname{demo}_{i t}=\gamma_{i}+\lambda_{t}+\beta \log \left(\text { integr }_{i t}\right)+\rho\left(\text { demo }_{i t-1}\right)+x_{i t}^{\prime} \delta+\varepsilon_{i t}
$$

whereas that for trade with democracies and autocracies separately is now:

$$
\text { demo }_{i t}=\gamma_{i}+\lambda_{t}+\beta^{\text {demo }} \log \left(\text { integr }_{i t}^{\text {demo }}\right)+\beta^{\text {auto }} \log \left(\text { integr }_{i t}^{\text {auto }}\right)+\rho\left(\text { demo }_{i t-1}\right)+x_{i t}^{\prime} \delta+\varepsilon_{i t}
$$

where the notation and variables are the same as in previous sections.

Dynamic panel data (DPD) models provide us with an estimate of the long-run effect of the regressors of interest on the dependent variable. ${ }^{30}$ In particular, they allow to operationalise the observation that, because of persistence, the impact on democracy of a rise in integration in a given period may be amplified over time. Specifically, the cumulative long-run effect on the dependent variable can be calculated as $\frac{\hat{\beta}^{g}}{1-\hat{\rho}}$ times the initial increase in integration.

Table 4 presents DPD results. Columns 1 and 4 report a first "naive" estimation of,

\footnotetext{
${ }^{29}$ The still high dimensionality of the problem prevented us from applying the standard error numerical adjustment procedure in column 6 .

${ }^{30}$ Acemoglu et al. (2008) and Acemoglu et al. (2015) are examples of papers that use our same method to calculate long-run effects.
} 
respectively, (8) and (9) (always without controls $x_{i t}$ ) based on a standard within estimator. The persistence in the democracy score emerges clearly by looking at the positive and significant $\hat{\rho}$. Contemporaneous effects are small and long-run ones (reported in Panel B) are close to their corresponding OLS estimates in Table 2.

To avoid Nickell (1981) bias, which is likely to be relevant in our short panel with 13 periods, in columns 2 and 5 we repeat the same estimations using the Arellano and Bond (1991) (AB from now on) GMM estimator. To partial out fixed effects from the model, we adopt the method of orthogonal deviations suggested in Arellano and Bover (1995). Results of this exercise show even smaller effects compared to the ones in columns 1 and 4 .

The DPD analysis presented so far, however, is based on the questionable assumption of exogeneity of integr $r_{i t}^{g}$. To address this concern, we add our IVs as further external instruments in the $\mathrm{AB}$ estimation procedure. Results for our preferred specifications, presented in columns 3 and 6, are now in line with their analogues in Table 2. ${ }^{31}$ Estimates in column 6 show once again that there is a sizeable and significant effect of trade with democratic partners on democracy (Panel A), which accumulates over time (Panel B). A long-run estimate of 7.1 implies that a country doubling its integration with democracies from one period to the next is predicted to experience a long-run increase in Polity2 of 7 points, ceteris paribus. This amounts to the 2014's difference in the democracy score between the US and Turkey. The effect of trade with autocracies is instead not significant, both in the short and in the long run.

Robustness checks for these findings are presented in subsequent columns of Table 4. Columns 7 to 9 replicate in a dynamic setting columns 5 to 7 of Table 2. Column 10 adds a second lag of the dependent variable as a regressor. ${ }^{32}$ Results remain broadly consistent under these alternative specifications, with just a slightly higher (and significant) effect of integration with autocracies in columns 6 and 7 .

Table 4 also reports the number of IVs used in the AB procedure and a number of statistical tests on the validity of the estimators. None of the latter raises particular concerns: the

\footnotetext{
${ }^{31}$ Again, we do not focus on the estimates of specification (8), given their lack of robustness.

${ }^{32}$ The long-run effect in this case of a double lag is computed as $\frac{\hat{\beta}^{g}}{1-\hat{\rho_{1}}-\hat{\rho_{2}}}$, where $\hat{\rho_{p}}$ is the estimated coefficient on lag $p$.
} 
null hypothesis for the test of the absence of serial correlation in the errors is never rejected (see AB AR2 p-val in Panel A). Similarly, the Hansen test of over-identifying restrictions does not reject the null hypothesis at conventional levels in the specifications of interest. Finally, finding that $\hat{\rho}$ is always substantially less than 1 is consistent with the stationarity of the process for Polity2.

\section{Mechanisms}

In this section, we discuss and provide evidence on the different channels through which economic integration can affect democratization. We start by arguing that, consistently with the literature and because of our IV strategy, our findings are unlikely to result from direct actions of ruling groups (Section 4.1). Then, we show that mechanisms commonly viewed as conducive to democracy, such as modernization and human capital accumulation (Section 4.2), or trade-induced changes in inequality (Section 4.3), are unlikely to explain our main results. Instead, we present suggestive evidence consistent with the learning hypothesis proposed in our work (Section 4.4).

\subsection{The Supply Side}

Economic integration can affect the process of democratization through a variety of channels. The first, important distinction to be drawn is between "supply" and "demand" factors that can promote or hinder institutional change. ${ }^{33}$

On the supply side, two possible mechanisms can be at play. First, ruling elites may decide to simultaneously undertake political and economic liberalizations. Similarly, relatively nondemocratic countries may first adopt more inclusive institutions and then gradually reduce trade barriers. While consistent with the existing evidence (Giavazzi and Tabellini, 2005, and Giuliano et al., 2013), this explanation can be ruled out by our empirical strategy, that exploits variation in economic integration orthogonal to the aforementioned political

\footnotetext{
${ }^{33}$ We refer to supply factors as changes coming only from decisions of the ruling group, keeping fixed the actions by other groups in the society. Similarly, by demand factors we mean forces that result from decisions by citizens/non-elite members, keeping fixed the actions of the elites.
} 
considerations.

Second, because of the transmission of ideas favoured by trade (e.g. Grossman and Helpman, 1991), the ruling groups may realise that democratic institutions outperform autocratic ones, and decide to democratise. Yet, the existing literature (both empirical and theoretical) is not supportive of this "efficient institutions" view: the extension of franchise has rarely emerged spontaneously. In fact, threats from other groups in the society usually explain why the ruling elites decide to move towards a more inclusive political system (see, among others, Acemoglu and Robinson, 2006).

In the next subsections, we turn to the discussion of "demand" factors through which economic integration can affect democracy.

\subsection{Income Effects and Human Capital Accumulation}

According to the "modernization hypothesis" originally proposed by Lipset (1959), the economic gains from trade may boost demand for democracy either directly, through an increase in income, or indirectly, by inducing human capital accumulation. In particular, the latter can favour the process of democratization by enabling citizens to better coordinate their actions and solve the collective action problem (as discussed, among others, by Glaeser et al., 2007). ${ }^{34}$

We start by noting that it is not immediate to reconcile the modernization hypothesis with the differential effect that we find for trade with democratic and non-democratic partners (see Tables 2 to 4 ). Nonetheless, one possible concern is that trade with democracies may have larger effects on either income growth or incentives to accumulate human capital. ${ }^{35} \mathrm{We}$ provide evidence that this is unlikely to be happening in our sample.

First, we augment our main specification (6) by controlling for GDP. We acknowledge that income is a "bad control" (Angrist and Pischke, 2008), as it is likely to be itself affected

\footnotetext{
${ }^{34}$ Consistently with this idea, Meyersson (2014) finds a strong, positive effect of human capital accumulation on political participation for women in Turkey.

${ }^{35}$ Note, however, that in a standard "comparative advantage" framework, less developed countries should specialise in the production of unskill-intensive goods, in turn reducing (rather than increasing) incentives to invest in human capital. Indeed, findings in Atkin (2015) and Blanchard and Olney (2015) are consistent with this idea and our results seem also to confirm this hypothesis.
} 
by trade. For this reason, our exercise should be interpreted as providing suggestive, but not conclusive, evidence. However, we believe that this can be a crude test to check if income has any direct effect on democracy: if the positive effect of economic integration on democracy estimated above were solely due to gains from trade, the coefficient on trade in (6) should become insignificant after including GDP, while that on GDP should be positive (and significant).

In fact, as shown in Table 5, exactly the opposite happens. In particular, we estimate (6) including log of real GDP (column 1), log of real GDP and log population (column 2), and $\log$ of real GDP per capita (column 3). The coefficients on trade with democracies remain large in magnitude and statistically significant, as in Table 2. Also, and importantly, coefficients on GDP are never statistically significant (with a negative point estimate). As just noted, one should be careful when interpreting these results, since GDP is likely to be itself an outcome of trade. ${ }^{36}$ Yet, Table 5 suggests that (trade-induced) income growth is unlikely to be driving the "democratizing" effect of economic integration estimated in our work.

Next, we study if economic integration has a positive effect on human capital accumulation in our sample. To do so, we re-estimate (6) using different measures of human capital from Barro and Lee (2013) as dependent variables. Results are reported in columns 4 and 5 of Table 5, where we regress, respectively, the fraction of the population with completed secondary schooling and average years of schooling on trade split between democratic and non-democratic partners.

In both cases, the coefficient on economic integration with democracies is negative. Moreover, in column 5, the estimated effect of trade with democracies is marginally significant, suggesting that average years of schooling decline when trading with democratic countries. While a deeper analysis of the relationship between trade and human capital acquisition goes beyond the scope of this paper, these findings suggest that the positive effect of economic integration on democracy is not due to increased human capital.

\footnotetext{
${ }^{36}$ These findings are robust to instrumenting income and population with their 5-year lags, and to controlling for the battery of variables included in Table 2 .
} 


\subsection{Trade-Induced Changes in Inequality}

Trade can widen the income gap between the elites and the rest of the society, in so doing rising citizens' discontent with the status quo and their incentives to push for institutional change. ${ }^{37}$ Also, economic openness can alter the political equilibrium by generating a redistribution of resources within the society. If groups that are made better off by trade are also those that are more likely to benefit from democracy (e.g. the middle class and/or merchants in Acemoglu et al., 2005), institutional change can emerge as a consequence of economic openness. In general, one may be concerned that the range of goods traded with democracies differs from that traded with autocracies, leading to inequality dynamics that depend on trade partners' institutions. In what follows, we provide evidence against the possibility that our main findings are unduly driven by these forces.

Specifically, we test whether results reported in Table 2 vary across countries, depending on characteristics that are likely to influence the pattern of comparative advantage, and thus the potential redistributional consequences of trade. Specifically, in Table 6, we augment (6) by interacting integration with democratic and autocratic partners with: i) a dummy for being an exporter of services (column 1); ii) the fraction of land devoted to agriculture (column 2); iii) the number of minerals in the country (column 3$) ;^{38}$ and $i v$ ) value added from, respectively, industry and agriculture (columns 4 and 5). ${ }^{39}$

The rationale behind this exercise is the following. If the redistributional consequences of trade were responsible for the democratizing effect of economic integration estimated in Table 2, then the coefficient on (at least some of) the interactions should be significant. Since it is hard to know a-priori the direction of trade-induced changes inequality, we chose to interact trade with a large number of proxies for patterns of comparative advantage.

\footnotetext{
${ }^{37}$ Autor et al. (2016) and Dippel et al. (2015) provide evidence consistent with the idea that trade-induced changes in inequality can alter the political equilibrium, even in "full democracies". In particular, these works show that import competition, and the associated increase in inequality, lead to political polarization and the rise of more "extremist" parties in, respectively, the US and Germany.

${ }^{38}$ Similar results are obtained when interacting trade with oil reserves rather than minerals.

${ }^{39} \mathrm{All}$ interacted variables are measured at baseline to limit possible simultaneity bias (due to the effect of trade on the pattern of specialization). To ease the interpretation of results, those in columns 2 to 5 are standardised to have zero mean and standard deviation equal to 1 . To save space, estimates for the direct effect of trade with autocracies and its interaction with variables in $(i)$ to $(i v)$ are not reported in Table 6.
} 
For instance, rents from natural resources are often largely appropriated by the elites, especially in less developed economies. If the effect of trade on democracy were due to citizens' discontent resulting from increased inequality between the ruling group and the rest of the population, the coefficient on the interaction between trade and the number of minerals should be positive and significant. ${ }^{40}$ Conversely, if economic integration triggers institutional change by favouring groups other than the elites, then one would expect a significant coefficient on the interaction with the dummy for being an exporter of services.

In all cases, the coefficient on the interaction term is insignificant and very imprecisely estimated. Also, and importantly, by comparing coefficients across columns, there is no systematic pattern suggesting that trade-induced changes in inequality may be driving our results. For example, the coefficient on the interaction with the number of minerals (column 3 ) is negative, whereas that on the interaction with value added from agriculture (column 5 ) is positive. While the evidence presented here is somewhat indirect, it nonetheless weighs against the possibility that our main results are driven by trade-induced changes in inequality or in the relative economic (and political) power of different groups in the society.

\subsection{Suggestive Evidence on the Learning Channel}

Finally, demand for democracy can increase with economic integration due to the presence of a learning/cultural transmission channel. Specifically, as non-democratic countries are exposed to their democratic partners' institutions, demand for democracy arises (or strengthens) if citizens perceive the benefits of a more inclusive political and economic system. Similarly, attitudes towards democracy may change, with people becoming more willing to limit the privileges and the power of the elites. As pressure from the rest of the population increases, the ruling group may be forced to extend franchise and broaden political participation. $^{41}$ As a result, institutions improve and democracy emerges.

Moreover, as shown by Grossman and Helpman (1991) among others, trade fosters growth by favouring the transmission of (economic) knowledge across and within countries. Hence,

\footnotetext{
${ }^{40} \mathrm{~A}$ similar reasoning applies to the interaction between trade and value added from agriculture and/or the fraction of land devoted to agriculture.

${ }^{41}$ See Acemoglu and Robinson (2006) for a more complete discussion of this mechanism.
} 
economic integration can increase the returns to democracy since, in autocratic regimes, the flow of ideas is usually deliberately restricted by the ruling groups, and this, in turn, is likely to reduce economic development. Anticipating the higher returns that can be achieved under democracy, citizens of autocratic countries may have stronger incentives to invest resources and push for institutional change, ultimately shifting the balance of political power away from the elites and towards themselves.

Our main finding that the democratizing effect of economic openness is driven by integration with democratic, rather than autocratic, partners is consistent with the existence of this institutional learning channel. In what follows, we provide further, suggestive evidence in favour of this mechanism.

\subsubsection{Splitting the Sample}

We start by showing that our results are driven by non-OECD members and, more broadly, by countries that were non-democratic at baseline. On the one hand, these results should not be surprising, since the Polity2 score of countries that were already democratic in the 1950s has often remained constant, and therefore most of the variation in our sample comes from less developed countries (LDCs). On the other hand, however, they are consistent with the existence of a learning channel, as these countries are precisely those that may have more to learn from their democratic partners.

In practice, we re-estimate expression (6) considering only: $i$ ) non-OECD members; $i i$ ) countries whose baseline Polity2 score is strictly positive; iii) years from 1960 (included) onwards. We report our findings in Table 7, including both OLS and 2SLS results for each of the three alternative samples considered. When restricting the analysis to non-OECD countries (columns 1 and 2), the gap between OLS and IV estimates increases, with the latter becoming larger than for the full sample (see Table 2, column 4). ${ }^{42}$ Conversely, when including only countries with baseline Polity2 score strictly positive (columns 3 and 4), results are no longer significant, with IV coefficients being negative and substantially smaller than OLS. Finally, when considering only years from 1960 onwards (columns 5 and 6), 2SLS

\footnotetext{
${ }^{42}$ A very similar patter of results (not shown for brevity) emerges when focusing on countries with nonpositive baseline Polity2 score.
} 
estimates are again larger than those shown in Table 2.

Overall, the evidence presented in Table 7 suggests that results are driven by countries that were non-democratic at baseline. Moreover, the rise in the coefficient of interest after 1960 is consistent with the fact that the relative number of autocracies, i.e. countries for which economic integration may foster democratization, grows over time in our sample (see Table A6 in the Appendix). ${ }^{43}$

\subsubsection{Heterogeneous Effects}

In this subsection we investigate possible heterogeneous effects by augmenting (6) an interaction between economic integration and a number of country-specific variables. In columns 1 to 4 of Table 8, we report results when trade is interacted, respectively, with: $i$ ) the baseline number of telephone lines per 100 people; ii) Polity2 score at baseline; iii) the index of ethnic polarization from Montalvo and Reynal-Querol (2005), standardised to have zero mean and standard deviation equal to 1 ; and $i v$ ) a dummy indicator for the presence of a state religion in 1900 from Barro and McCleary (2005). ${ }^{44}$

In the presence of a learning channel, one would expect countries with lower baseline levels of institutional and/or economic development to benefit more from economic integration, as these countries should have more to learn from their (more) democratic partners. That is, the interaction between trade with democracies and baseline indicators of economic (column 1) and institutional (column 2) development should be negative and significant. Results, reported in Table 8 (columns 1 and 2), are in line with this hypothesis: economic integration has a stronger effect on the process of democratization in countries with lower institutional and infrastructural quality at baseline.

In columns 3 and 4 we indirectly test two additional implications of our proposed learning mechanism. First, in more ethnically polarised countries, the diffusion of information within the society should be more limited. Hence, since trade directly affects the perception of

\footnotetext{
${ }^{43}$ Consistently with this interpretation, when repeating the analysis considering only years from 1970 onwards and from 1980 onwards, results (not reported for the sake of brevity) become stronger and stronger over time.

${ }^{44}$ As in Table 6, results for the direct effect of trade with autocracies and its interaction with variables in (i) to (iv) are not reported for brevity. Reassuringly, none of these coefficients is significant.
} 
democracy only for some citizens (i.e. those directly exposed to economic integration), attitudes towards democratic institutions for the population as a whole should change more slowly. In turn, demand for institutional change should be less likely to reach the critical mass needed for democratization. ${ }^{45}$ Consistently with this idea, the interaction between trade with democracies and the Montalvo and Reynal-Querol (2005) polarization index is negative and significant (column 3). ${ }^{46}$

Second, if economic integration promotes institutional change by altering citizens' perceptions of democracy, this effect should be stronger in countries where some forms of restriction to the flow of information on different institutions has been historically in place. We proxy for this using a dummy for the presence of a state religion in 1900 (Barro and McCleary, 2005). As shown in column 4, the interaction between the latter variable and trade with democracies is positive, albeit not statistically significant. We interpret this as suggestive evidence that economic integration may operate as an external force that reduces informational barriers and makes people aware of institutional arrangements in other countries.

To sum up, while results in Tables 7 and 8 may be consistent with other mechanisms, they are nonetheless supportive of an institutional learning channel. This interpretation is reinforced by our findings that modernization and human capital accumulation (Table 5), and trade-induced changes in inequality (Table 6) are unlikely to account for the democratizing effect of trade with democracies documented throughout our work.

\section{Conclusions}

In this paper, we study if, and through which channels, economic integration can foster democracy, by instrumenting actual trade with predicted trade obtained from a time-varying gravity equation. Extending the strategy used in Feyrer (2009), we exploit the fact that air transportation has become more and more important relative to sea transportation over the last 60 years (as documented in Hummels, 2007). A time-varying instrument for trade

\footnotetext{
${ }^{45}$ Demand-driven institutional change may be slowed down in a more polarised country also because, there, solving the collective action problem is more costly.

${ }^{46}$ Similar results, though less precisely estimated, are obtained when considering the index of linguistic fragmentation of Alesina et al. (2003).
} 
(or, more broadly, economic integration) permits the inclusion of time and country fixed effects in the regression of interest, in turn reducing endogeneity concerns that permeate existing cross-country studies. We test the robustness of our results to the use of alternative specifications and, to deal with the persistent nature of democracy, we repeat the analysis using a dynamic panel model.

We find that economic integration has a positive effect on democracy that is driven by trade with democratic partners, tends to accumulate over time, and is stronger for countries with lower initial levels of democracy and infrastructural development. Our preferred interpretation is that demand for democracy increases with economic integration due to the presence of a learning/cultural transmission channel, whereby less democratic countries learn from the institutions of their (more) democratic partners. We corroborate this interpretation by providing evidence against alternative mechanisms, such as income effects, human capital acquisition, and trade-induced changes in inequality.

Our results provide motivation for future work along several directions. First, it would be interesting to unveil the exact mechanisms through which the trade-induced learning process operates. For this, a different empirical setting, with more micro-based evidence on changes in citizens' attitudes towards alternative institutional arrangements is needed. Second, in order to improve upon the reduced-form nature of our results and ask counterfactual questions, one could develop and estimate a structural learning model that relates trade and democratization. 


\section{References}

Acemoglu, D., S. Johnson, and J. Robinson (2005). The rise of europe: Atlantic trade, institutional change, and economic growth. American Economic Review 95(3), 546-579.

Acemoglu, D., S. Johnson, J. A. Robinson, and P. Yared (2008). Income and democracy. American Economic Review 98(3), 808-842.

Acemoglu, D., S. Naidu, P. Restrepo, and J. A. Robinson (2015). Democracy does cause growth. Working paper, MIT.

Acemoglu, D. and J. A. Robinson (2006). Economic Origins of Dictatorship and Democracy. New York: Cambridge University Press.

Alesina, A., A. Devleeschauwer, W. Easterly, S. Kurlat, and R. Wacziarg (2003). Fractionalization. Journal of Economic Growth 8(2), 155-194.

Alesina, A. and P. Giuliano (2015). Culture and institutions. Journal of Economic Literature 53(4), 898-944.

Alesina, A., J. Harnoss, and H. Rapoport (2016). Birthplace diversity and economic prosperity. Journal of Economic Growth 21(2), 101-138.

Alvarez, F. E., F. J. Buera, and J. Robert E. Lucas (2013). Idea flows, economic growth, and trade. Working Paper 19667, National Bureau of Economic Research.

Anderson, J. E. and E. Van Wincoop (2003). Gravity with gravitas: a solution to the border puzzle. American Economic Review 93(1), 170-192.

Angrist, J. D. (2014). The perils of peer effects. Labour Economics 30, 98-108.

Angrist, J. D. and J.-S. Pischke (2008). Mostly harmless econometrics: An empiricist's companion. Princeton university press.

Arellano, M. and S. Bond (1991). Some tests of specification for panel data: Monte carlo evidence and an application to employment equations. The Review of Economic Studies 58(2), 277-297. 
Arellano, M. and O. Bover (1995). Another look at the instrumental variable estimation of error-components models. Journal of Econometrics 68(1), 29-51.

Atkin, D. (2015). Endogenous skill acquisition and export manufacturing in mexico. Working paper, MIT.

Autor, D., D. Dorn, G. Hanson, and K. Majlesi (2016). Importing political polarization? the electoral consequences of rising trade exposure. Working paper, MIT.

Baldwin, R. and D. Taglioni (2007). Trade effects of the euro: A comparison of estimators. Journal of Economic Integration 22(4), 780-818.

Barro, R. J. and J. W. Lee (2013). A new data set of educational attainment in the world, 1950-2010. Journal of Development Economics 104, 184-198.

Barro, R. J. and R. M. McCleary (2005). Which countries have state religions? The Quarterly Journal of Economics 120(4), 1331-1370.

Bazzi, S. and M. A. Clemens (2013). Blunt instruments: Avoiding common pitfalls in identifying the causes of economic growth. American Economic Journal: Macroeconomics 5(2), $152-86$.

Blanchard, E. and W. Olney (2015). Globalization and human capital investment: How export composition drives educational attainment. Working paper.

Buera, F. J., A. Monge-Naranjo, and G. E. Primiceri (2011). Learning the wealth of nations. Econometrica $79(1), 1-45$.

Costinot, A. (2009). An elementary theory of comparative advantage. Econometrica rry(4), 1165-1192.

Dippel, C., R. Gold, and S. Heblich (2015). Globalization and its (dis-)content: Trade shocks and voting behavior. Working Paper 21812, National Bureau of Economic Research.

Feyrer, J. (2009). Trade and income-exploiting time series in geography. Working Paper 14910, National Bureau of Economic Research. 
Frankel, J. A. and D. Romer (1999). Does trade cause growth? American Economic Review 89(3), 379-399.

Giavazzi, F. and G. Tabellini (2005). Economic and political liberalizations. Journal of Monetary Economics 52(7), 1297-1330.

Giuliano, P., P. Mishra, and A. Spilimbergo (2013). Democracy and reforms: evidence from a new dataset. American Economic Journal: Macroeconomics 5(4), 179-204.

Glaeser, E. L., G. A. Ponzetto, and A. Shleifer (2007). Why does democracy need education? Journal of Economic Growth 12(2), 77-99.

Grossman, G. M. and E. Helpman (1991). Trade, knowledge spillovers, and growth. European Economic Review 35(2), $517-526$.

Grossman, G. M. and E. Helpman (2015). Globalization and growth. American Economic Review 105(5), 100-104.

Guiso, L., P. Sapienza, L. Zingales, et al. (2009). Cultural biases in economic exchange? The Quarterly Journal of Economics 124(3), 1095-1131.

Head, K. and T. Mayer (2014). Chapter 3 - gravity equations: Workhorse, toolkit, and cookbook. In E. H. Gita Gopinath and K. Rogoff (Eds.), Handbook of International Economics, Volume 4, pp. 131 - 195.

Hummels, D. (2007). Transportation costs and international trade in the second era of globalization. The Journal of Economic Perspectives 21(3), 131-154.

Levchenko, A. A. (2007). Institutional quality and international trade. The Review of Economic Studies $74(3), 791-819$.

Lipset, S. M. (1959). Some social requisites of democracy: Economic development and political legitimacy. American Political Science Review 53(1), 69-105.

López-Córdova, J. E. and C. M. Meissner (2008). The impact of international trade on democracy: A long-run perspective. World Politics 60(4), 539-575. 
Mayer, T. and S. Zignago (2011). Notes on CEPIIs distances measures: The GeoDist database. Working Papers 2011-25, CEPII research center.

Meyersson, E. (2014). Islamic rule and the empowerment of the poor and pious. Econometrica 82(1), 229-269.

Montalvo, J. G. and M. Reynal-Querol (2005). Ethnic polarization, potential conflict, and civil wars. American Economic Review 95(3), 796-816.

Nickell, S. (1981). Biases in dynamic models with fixed effects. Econometrica 49(6), 14171426.

Nunn, N. (2007). Relationship-specificity, incomplete contracts, and the pattern of trade. The Quarterly Journal of Economics 122(2), 569-600.

Papaioannou, E. and G. Siourounis (2008). Democratisation and growth. The Economic Journal 118(532), 1520-1551.

Parker, P. M. (1997). National Cultures of the World: A Statistical Reference, Cross-Cultural Statistical Encyclopedia of the World, volume 4, Connecticut. Westport, CT: Greenwood Press.

Pascali, L. (Forthcoming). The wind of change: Maritime technology, trade and economic development. American Economic Review.

Persson, T. and G. Tabellini (2008). The growth effect of democracy: Is it heterogenous and how can it be estimated? Harvard University Press.

Persson, T. and G. Tabellini (2009). Democratic capital: The nexus of political and economic change. American Economic Journal: Macroeconomics 1(2), 88-126.

Puga, D. and D. Trefler (2014). International trade and institutional change: Medieval venices response to globalization. The Quarterly Journal of Economics 129(2), 753-821.

Rigobon, R. and D. Rodrik (2005). Rule of law, democracy, openness, and income. Economics of Transition 13(3), 533-564. 
Rodrik, D. and R. Wacziarg (2005). Do democratic transitions produce bad economic outcomes? American Economic Review 95(2), 50-55.

Sampson, T. (2016). Dynamic selection: An idea flows theory of entry, trade, and growth. The Quarterly Journal of Economics 131(1), 315-380.

Santos Silva, Joao, M. and S. Tenreyro (2006). The log of gravity. The Review of Economics and Statistics 88(4), 641-658.

Stock, J. H. and M. Yogo (2005). Testing for weak instruments in linear iv regression. Identification and inference for econometric models: Essays in honor of Thomas Rothenberg. 
Table 1: Summary Statistics

\begin{tabular}{lcccccccc}
\hline Variable & Mean & Std Deviation & $\mathrm{p} 5$ & $\mathrm{p} 25$ & $\mathrm{p} 50$ & $\mathrm{p} 75$ & $\mathrm{p} 95$ & Obs \\
\hline Polity2 & 1.727 & 7.410 & -9 & -7 & 4 & 9 & 10 & 1152 \\
dpolity & 0.558 & 0.497 & 0 & 0 & 1 & 1 & 1 & 1152 \\
demo_fh & 0.557 & 0.497 & 0 & 0 & 1 & 1 & 1 & 869 \\
integration & 0.283 & 0.681 & 0.060 & 0.135 & 0.202 & 0.297 & 0.570 & 1152 \\
integration_demo & 0.232 & 0.584 & 0.045 & 0.109 & 0.170 & 0.247 & 0.456 & 1152 \\
integration_auto & 0.051 & 0.139 & 0.003 & 0.013 & 0.025 & 0.049 & 0.161 & 1152 \\
\hline
\end{tabular}

Notes: All statistics are calculated for the sample of Table 2, but from the ones for demo_fh, which refer to the sample of Table 3, column 6. The period covered is 1955-2010 (included), with observations at 5-year frequency. Polity2 is the democracy score from the Polity IV project. dpolity is a dichotomous version of Polity2, while demo_fh is another dummy variable to measure democracy based on Freedom House data (see Section 2.3 for details). integration refers to trade over GDP, considered both together and separately for democratic and autocratic partners. p\# refers to the $\#^{\text {th }}$ percentile of the sample distribution. 
Table 2: Economic Integration and Democracy: Baseline Results

\begin{tabular}{|c|c|c|c|c|c|c|c|}
\hline & $(1)$ & $(2)$ & (3) & (4) & $(5)$ & (6) & (7) \\
\hline & OLS & 2SLS & OLS & 2SLS & 2SLS & 2SLS & 2SLS \\
\hline \multicolumn{8}{|c|}{ PANEL A - OLS and SECOND STAGE: dep var is Polity2 } \\
\hline \multirow[t]{2}{*}{$\log$ (integration) } & $1.146^{* *}$ & $2.855^{*}$ & & & & & \\
\hline & $(0.544)$ & $(1.718)$ & & & & & \\
\hline \multirow[t]{2}{*}{$\log ($ integration_demo) } & & & $1.710^{* * *}$ & $3.414^{* *}$ & $3.535^{* *}$ & $3.219^{* *}$ & $2.727^{* *}$ \\
\hline & & & $(0.550)$ & $(1.480)$ & $(1.382)$ & $(1.449)$ & $(1.257)$ \\
\hline \multirow[t]{2}{*}{$\log ($ integration_auto) } & & & $-0.594^{* *}$ & -0.606 & -0.107 & -0.952 & -0.898 \\
\hline & & & $(0.270)$ & $(0.614)$ & $(0.567)$ & $(0.595)$ & $(0.558)$ \\
\hline F-stat for weak IVs & & 16.783 & & 7.452 & 8.018 & 7.980 & 7.306 \\
\hline \multicolumn{8}{|c|}{ PANEL B - FIRST STAGE: dep var is log(integration) } \\
\hline \multirow[t]{2}{*}{$\log$ (pred_integration) } & & $0.250^{* * *}$ & & & & & \\
\hline & & $(0.061)$ & & & & & \\
\hline \multicolumn{8}{|c|}{ PANEL C - FIRST STAGE: dep var is $\log$ (integration_demo) } \\
\hline \multirow[t]{2}{*}{$\log ($ pred_integration_demo) } & & & & $0.279^{* * *}$ & $0.274^{* * *}$ & $0.281^{* * *}$ & $0.282^{* * *}$ \\
\hline & & & & $(0.062)$ & $(0.061)$ & $(0.063)$ & $(0.060)$ \\
\hline \multirow[t]{2}{*}{$\log ($ pred_integration_auto) } & & & & -0.016 & -0.005 & -0.002 & -0.022 \\
\hline & & & & $(0.040)$ & $(0.039)$ & $(0.041)$ & $(0.042)$ \\
\hline \multicolumn{4}{|l|}{ AP F-stat for log(integration_demo) } & 10.239 & 10.270 & 10.209 & 11.253 \\
\hline \multicolumn{8}{|c|}{ PANEL D - FIRST STAGE: dep var is log(integration_auto) } \\
\hline \multirow[t]{2}{*}{$\log ($ pred_integration_demo) } & & & & $-0.314^{* * *}$ & $-0.317^{* * *}$ & $-0.316^{* * *}$ & $-0.314^{* * *}$ \\
\hline & & & & $(0.098)$ & $(0.097)$ & $(0.101)$ & $(0.096)$ \\
\hline \multirow[t]{2}{*}{ log(pred_integration_auto) } & & & & $0.525^{* * *}$ & $0.533^{* * *}$ & $0.531^{* * *}$ & $0.523^{* * *}$ \\
\hline & & & & $(0.055)$ & $(0.055)$ & $(0.061)$ & $(0.056)$ \\
\hline AP F-stat for log(integration_auto) & & & & 51.644 & 54.049 & 44.103 & 50.064 \\
\hline Observations & 1,152 & 1,152 & 1,152 & 1,152 & 1,152 & 1,152 & 1,152 \\
\hline Number of countries & 116 & 116 & 116 & 116 & 116 & 116 & 116 \\
\hline
\end{tabular}

Notes: The dependent variable is reported at the top of each Panel. The main regressor of interest in Panel A is (log) trade over GDP, considered together in columns 1-2 and separately for democratic and autocratic partners in columns 3-7. Actual trade is instrumented with predicted trade as described in the main text (see Sections 2.1 and 2.2), where democratic (autocratic) partners are defined as partners with Polity2 score five years before strictly positive (non-positive). Column 5 controls for demo_wave. Columns 6 and 7 include interactions between year dummies and dummies for non-OECD country, and baseline non-democracy, respectively. All regressions are estimated on 1955-2010 data at 5-year frequency, and include year and country fixed effects. AP F-stat refers to the (robust) F-stat for the Angrist and Pischke weak identification test for each individual endogenous regressor. The F-stat for weak IVs is the Kleibergen-Paap Wald rk statistics for (jointly) weak instruments. Standard errors (reported in parentheses) are clustered at the country level, and the ones for 2SLS and First Stages are corrected to account for the fact that the instruments depend on the (estimated) parameters of the bilateral trade equation; ${ }^{* * *} p<0.01,{ }^{* *} p<0.05,{ }^{*} p<0.1$ 
Table 3: Economic Integration and Democracy: Robustness

\begin{tabular}{|c|c|c|c|c|c|c|}
\hline VARIABLES & $\begin{array}{c}(1) \\
\text { Baseline }\end{array}$ & $\begin{array}{c}(2) \\
\text { No Outliers }\end{array}$ & $\begin{array}{c}(3) \\
\text { No USSR }\end{array}$ & $\begin{array}{c}(4) \\
\text { No Weights }\end{array}$ & $\begin{array}{c}(5) \\
\text { dpolity }\end{array}$ & $\begin{array}{c}(6) \\
\text { demo_fh }\end{array}$ \\
\hline \multicolumn{7}{|c|}{ PANEL A - SECOND STAGE } \\
\hline \multirow[t]{2}{*}{$\log ($ integration_demo) } & $3.414^{* *}$ & $5.374^{* * *}$ & $3.435^{* *}$ & $4.309^{* *}$ & $0.243^{* *}$ & $0.252^{*}$ \\
\hline & $(1.480)$ & $(1.933)$ & $(1.489)$ & $(2.133)$ & $(0.111)$ & $(0.133)$ \\
\hline \multirow[t]{2}{*}{$\log$ (integration_auto) } & -0.606 & -0.124 & -0.605 & -0.129 & -0.053 & -0.041 \\
\hline & $(0.614)$ & $(0.728)$ & $(0.613)$ & $(0.681)$ & $(0.048)$ & $(0.056)$ \\
\hline F-stat for weak IVs & 7.452 & 4.049 & 7.344 & 6.532 & 7.452 & 6.140 \\
\hline \multicolumn{7}{|c|}{ PANEL B - FIRST STAGE: dep var is log(integration_demo) } \\
\hline \multirow[t]{2}{*}{$\log ($ pred_integration_demo $)$} & $0.279^{* * *}$ & $0.268^{* * *}$ & $0.280^{* * *}$ & $0.223^{* *}$ & $0.279^{* * *}$ & $0.323^{* * *}$ \\
\hline & $(0.062)$ & $(0.076)$ & $(0.062)$ & $(0.095)$ & $(0.062)$ & $(0.071)$ \\
\hline \multirow[t]{2}{*}{ log(pred_integration_auto) } & -0.016 & -0.020 & -0.016 & 0.014 & -0.016 & -0.053 \\
\hline & $(0.040)$ & $(0.046)$ & $(0.040)$ & $(0.070)$ & $(0.040)$ & $(0.043)$ \\
\hline AP F-stat for log(integration_demo) & 10.239 & 6.184 & 10.161 & 6.266 & 10.239 & 11.472 \\
\hline \multicolumn{7}{|c|}{ PANEL C - FIRST STAGE: dep var is log(integration_auto) } \\
\hline \multirow[t]{2}{*}{$\log ($ pred_integration_demo) } & $-0.314^{* * *}$ & $-0.368^{* * *}$ & $-0.319^{* * *}$ & $-0.923^{* * *}$ & $-0.314^{* * *}$ & $-0.185^{* *}$ \\
\hline & $(0.098)$ & $(0.126)$ & $(0.098)$ & $(0.206)$ & $(0.096)$ & $(0.085)$ \\
\hline \multirow[t]{2}{*}{ log(pred_integration_auto) } & $0.525^{* * *}$ & $0.565^{* * *}$ & $0.526^{* * *}$ & $1.094^{* * *}$ & $0.525^{* * *}$ & $0.485^{* * *}$ \\
\hline & $(0.055)$ & $(0.065)$ & $(0.055)$ & $(0.163)$ & $(0.052)$ & $(0.061)$ \\
\hline AP F-stat for log(integration_auto) & 51.644 & 43.541 & 52.004 & 28.850 & 51.644 & 34.940 \\
\hline Observations & 1,152 & 1,080 & 1,128 & 1,152 & 1,152 & 869 \\
\hline Number of countries & 116 & 116 & 110 & 116 & 116 & 116 \\
\hline
\end{tabular}

Notes: The dependent variable in Panel A is Polity2 in columns 1-4, dpolity in column 5, and demo_fh in column 6. Column 2 drops observations with a standardised residual in column 1 that is larger than 1.96 in absolute value. Column 3 removes ex-USSR countries from the sample in column 1. Column 4 is identical to column 1, but from the fact that the IVs are built without any weight in formula (4). Columns 5 and 6 are identical to column 1, apart from using different dependent variables. The main regressors of interest in Panel A are (log) trade with democratic and autocratic partners divided by GDP. Actual trade is instrumented with predicted trade as described in the main text (see Sections 2.1 and 2.2), where democratic (autocratic) partners are defined as partners with Polity2 score five years before strictly positive (non-positive). All regressions are estimated on 1955-2010 data at 5-year frequency, and include country and time fixed effects. AP F-stat refers to the (robust) F-stat for the Angrist and Pischke weak identification test for each individual endogenous regressor. The F-stat for weak IVs is the Kleibergen-Paap Wald rk statistics for (jointly) weak instruments. Standard errors (reported in parentheses) are clustered at the country level, and the ones for 2SLS and First Stages are corrected to account for the fact that the instruments depend on the (estimated) parameters of the bilateral trade equation; ${ }^{* * *} p<0.01,{ }^{* *}$ $p<0.05,{ }^{*} p<0.1$ 


\section{Table 4: Economic Integration and Democracy: Dynamic Panel}

\begin{tabular}{|c|c|c|c|c|c|c|c|c|c|c|}
\hline & (1) & $(2)$ & $(3)$ & $(4)$ & (5) & (6) & $(7)$ & (8) & (9) & $(10)$ \\
\hline VARIABLES & OLS & GMM & GMM & OLS & GMM & GMM & GMM & GMM & GMM & GMM \\
\hline \multicolumn{11}{|c|}{ PANEL A - DPD: dep var is Polity2 } \\
\hline \multirow[t]{2}{*}{$\log ($ integration $)$} & 0.598 & 0.341 & $3.045^{* * *}$ & & & & & & & \\
\hline & $(0.366)$ & $(0.343)$ & $(0.968)$ & & & & & & & \\
\hline \multirow[t]{2}{*}{$\log ($ integration_demo) } & & & & $0.861^{* *}$ & 0.376 & $2.616^{* * *}$ & $2.557^{* * *}$ & $3.044^{* * *}$ & $2.491^{* * *}$ & $2.252^{* *}$ \\
\hline & & & & $(0.364)$ & $(0.320)$ & $(0.788)$ & $(0.750)$ & $(0.875)$ & $(0.807)$ & $(0.880)$ \\
\hline \multirow[t]{2}{*}{$\log ($ integration_auto) } & & & & -0.239 & -0.079 & $0.746^{*}$ & $0.854^{* *}$ & 0.710 & 0.529 & 0.571 \\
\hline & & & & $(0.182)$ & $(0.173)$ & $(0.449)$ & $(0.424)$ & $(0.436)$ & $(0.517)$ & $(0.431)$ \\
\hline \multirow[t]{2}{*}{ L.polity2 } & $0.510^{* * *}$ & $0.692^{* * *}$ & $0.653^{* * *}$ & $0.500^{* * *}$ & $0.697 * * *$ & $0.632^{* * *}$ & $0.566^{* * *}$ & $0.604^{* * *}$ & $0.555^{* * *}$ & $0.605^{* * *}$ \\
\hline & $(0.047)$ & $(0.068)$ & $(0.064)$ & $(0.048)$ & $(0.074)$ & $(0.066)$ & $(0.072)$ & $(0.074)$ & $(0.084)$ & $(0.069)$ \\
\hline
\end{tabular}

L2.polity2

$0.084^{*}$

$(0.050)$

p-val lags 3-6

0.391

\begin{tabular}{|c|c|c|c|c|c|c|c|c|c|c|}
\hline Number of AB IVs & & 78 & 78 & & 79 & 79 & 80 & 90 & 90 & 77 \\
\hline External IVs & & NO & YES & & NO & YES & YES & YES & YES & YES \\
\hline AB AR2 p-val & & 0.397 & 0.383 & & 0.403 & 0.418 & 0.491 & 0.450 & 0.457 & 0.985 \\
\hline Hansen p-val & & 0.0365 & 0.0816 & & 0.0432 & 0.122 & 0.142 & 0.181 & 0.241 & 0.0629 \\
\hline \multicolumn{11}{|c|}{ PANEL B - LONG-RUN EFFECTS } \\
\hline L-R effect of integr & 1.219 & 1.107 & $8.758^{* * *}$ & & & & & & & \\
\hline p-value & 0.105 & 0.326 & 0.005 & & & & & & & \\
\hline L-R effect of integr_demo & & & & $1.721^{* *}$ & 1.237 & $7.124^{* * *}$ & $5.903^{* * *}$ & $7.700^{* * *}$ & $5.609^{* * *}$ & $7.270^{* * *}$ \\
\hline p-value & & & & 0.016 & 0.217 & 0.001 & 0.0004 & 0.0005 & 0.003 & 0.003 \\
\hline L-R effect of integr_auto & & & & -0.475 & -0.254 & 2.002 & $1.946^{*}$ & 1.772 & 1.167 & 1.800 \\
\hline $\mathrm{p}$-value & & & & 0.178 & 0.640 & 0.138 & 0.0679 & 0.150 & 0.359 & 0.240 \\
\hline Observations & 1,099 & 983 & 983 & 1,099 & 983 & 983 & 983 & 983 & 983 & 881 \\
\hline Number of countries & 116 & 116 & 116 & 116 & 116 & 116 & 116 & 116 & 116 & 116 \\
\hline
\end{tabular}

Notes: The dependent variable is Polity2. The main regressor of interest is (log) trade over GDP, considered together in columns 1-3 and separately for democratic and autocratic partners in columns 4-10. The long-run effects reported in Panel B are calculated as described in Section 3.4. Columns 1 and 4 report results obtained from a classical within estimators, while all other columns show results for the Arellano-Bond difference GMM estimator with orthogonal deviations. In Columns 3 and 6-10, actual trade is instrumented with predicted trade as described in the main text (see Sections 2.1 and 2.2), where democratic (autocratic) partners are defined as partners with Polity2 score five years before strictly positive (non-positive). Column 7 controls for demo_wave. Columns 8 and 9 include interactions between year dummies and dummies for non-OECD country, and baseline non-democracy, respectively. Column 10 controls for an additional second lag of Polity2. The p-val lags 3-6 in column 10 is the p-value of the test of null coefficients on lags 3 to 6 of Polity2. All regressions are estimated on 1955-2010 data at 5-year frequency, and include year and country fixed effects. The Number of AB IVs is the number of IVs (exogenous regressors and lags of the dependent variable) used in deriving the GMM estimates. It does not include the external IVs used in Cols 3 and 6-10. AB AR2 p-value is the p-value of the Arellano-Bond test for serially correlated errors. Hansen p-value is the p-value of the Hansen (robust) tests of over-identifying restrictions. Standard errors (reported in parentheses) are clustered at the country level, and the ones involving the external IVs are corrected to account for the fact that the instruments depend on the (estimated) parameters of the bilateral trade equation; ${ }^{* * *} p<0.01,{ }^{* *} p<0.05,{ }^{*} p<0.1$ 
Table 5: Income Effects and Human Capital Accumulation

\begin{tabular}{|c|c|c|c|c|c|}
\hline & $(1)$ & $(2)$ & $(3)$ & $(4)$ & $(5)$ \\
\hline & Polity2 & Polity2 & Polity2 & $\%$ Secondary & Years of School \\
\hline \multirow[t]{2}{*}{ log(integration_demo) } & $2.805^{* *}$ & $3.181^{* *}$ & $2.283^{* *}$ & -0.990 & $-0.997^{*}$ \\
\hline & $(1.192)$ & $(1.300)$ & $(1.142)$ & $(3.588)$ & $(0.526)$ \\
\hline \multirow[t]{2}{*}{$\log ($ integration_auto) } & -0.675 & $-1.154^{*}$ & -0.885 & $-1.738^{*}$ & -0.014 \\
\hline & $(0.588)$ & $(0.695)$ & $(0.611)$ & $(1.000)$ & $(0.140)$ \\
\hline \multirow[t]{2}{*}{$\log (\mathrm{rGDP})$} & -0.335 & -0.528 & & & \\
\hline & $(0.564)$ & $(0.618)$ & & & \\
\hline \multirow[t]{2}{*}{$\log ($ population $)$} & & 2.547 & & & \\
\hline & & $(1.785)$ & & & \\
\hline \multirow[t]{2}{*}{$\log ($ rGDP_pc $)$} & & & -0.737 & & \\
\hline & & & $(0.625)$ & & \\
\hline Observations & 1,152 & 1,152 & 1,152 & 1,035 & 1,035 \\
\hline Number of countries & 116 & 116 & 116 & 102 & 102 \\
\hline F-stat for weak IVs & 15.910 & 16.325 & 14.959 & 4.864 & 4.864 \\
\hline AP F-stat for $\log$ (integration_demo) & 22.697 & 20.927 & 23.592 & 6.999 & 6.999 \\
\hline AP F-stat for log(integration_auto) & 45.929 & 28.088 & 33.589 & 49.805 & 49.805 \\
\hline
\end{tabular}

Notes: In columns 1,2,3, the dependent variable is Polity2, while in columns 4,5, it is, respectively, the fraction of the population with completed secondary schooling and average years of schooling. The main regressors of interest are (log) trade with democratic and autocratic partners divided by GDP. In addition, columns 1,2,3 control respectively for log real GDP, both log real GDP and log population, and log real GDP per capita. Actual trade is instrumented with predicted trade as described in the main text (see Sections 2.1 and 2.2), where democratic (autocratic) partners are defined as partners with Polity2 score five years before strictly positive (non-positive). All regressions are estimated on 1955-2010 data at 5-year frequency, and include year and country fixed effects. AP F-stat refers to the (robust) F-stat for the Angrist and Pischke weak identification test for each individual endogenous regressor. The F-stat for weak IVs is the KleibergenPaap Wald rk statistics for (jointly) weak instruments. Standard errors (reported in parentheses) are clustered at the country level and are corrected to account for the fact that the instruments depend on the (estimated) parameters of the bilateral trade equation; ${ }^{* * *} p<0.01,{ }^{* *} p<0.05,{ }^{*} p<0.1$ 


\section{Table 6: Trade-Induced Changes in Inequality and Democracy}

\begin{tabular}{|c|c|c|c|c|c|}
\hline & $(1)$ & $(2)$ & $(3)$ & $(4)$ & $(5)$ \\
\hline & 2SLS & 2SLS & 2SLS & 2SLS & 2SLS \\
\hline \multirow[t]{2}{*}{$\log ($ integration_demo $)$} & $3.045^{*}$ & $4.350^{* *}$ & $3.115^{* *}$ & 0.657 & 0.941 \\
\hline & $(1.588)$ & $(1.804)$ & $(1.362)$ & $(1.809)$ & $(1.716)$ \\
\hline \multirow[t]{2}{*}{$\log (\text { integration_demo })^{*} 1$ (service exporter) } & 8.681 & & & & \\
\hline & $(8.222)$ & & & & \\
\hline \multirow[t]{2}{*}{$\log ($ integration_demo $) *($ Agric. Land $)$} & & -0.077 & & & \\
\hline & & $(1.250)$ & & & \\
\hline \multirow[t]{2}{*}{$\log ($ integration_demo $) *($ Minerals $)$} & & & -1.075 & & \\
\hline & & & $(0.820)$ & & \\
\hline \multirow[t]{2}{*}{$\log (\text { integration_demo })^{*}($ Industry value added $)$} & & & & 0.875 & \\
\hline & & & & $(1.364)$ & \\
\hline \multirow[t]{2}{*}{$\log ($ integration_demo $) *($ Agriculture value added $)$} & & & & & 1.655 \\
\hline & & & & & $(1.415)$ \\
\hline Observations & 1,148 & 1,027 & 1,152 & 886 & 895 \\
\hline Number of countries & 115 & 114 & 116 & 112 & 112 \\
\hline F-stat for weak IV & 3.226 & 2.571 & 3.932 & 2.807 & 4.205 \\
\hline AP F-stat for log(integration_demo) & 9.676 & 5.664 & 5.563 & 6.950 & 7.641 \\
\hline AP F-stat for interaction with $\log$ (integration_demo) & 7.308 & 22.913 & 6.146 & 12.381 & 9.583 \\
\hline
\end{tabular}

Notes: The dependent variable is Polity2. The main regressors of interest are (log) trade with democratic partners divided by GDP and its interaction with, respectively: i) a dummy for being an exporter of services (column 1); ii) the fraction of land devoted to agriculture (column 2 ); iii) the number of minerals in the country (column 3); iv) value added from industry (column 4) and agriculture (column 5 ). All variables in the interactions are measured at baseline and the ones in columns 2 to 5 are standardised to have zero mean and standard deviation equal to 1. Actual trade is instrumented with predicted trade as described in the main text (see Sections 2.1 and 2.2). All regressions always include the $\log$ of trade with autocratic partners divided by GDP and its interaction with variables (i)-(iv) above (coefficients on these variables not shown for brevity). Democratic (autocratic) partners are defined as partners with Polity2 score five years before strictly positive (non-positive). All regressions are estimated on 1955-2010 data at 5-year frequency, and include year and country fixed effects. AP F-stat refers to the (robust) F-stat for the Angrist and Pischke weak identification test for log trade with democratic partners (divided by GDP) and its interaction. The AP F-stats for trade with autocratic partners and its interactions are not reported for brevity. The F-stat for weak IVs is the Kleibergen-Paap Wald rk statistics for (jointly) weak instruments. Standard errors (reported in parentheses) are clustered at the country level and are corrected to account for the fact that the instruments depend on the (estimated) parameters of the bilateral trade equation; *** $p<0.01, * * p<0.05, *$ $p<0.1$ 
Table 7: Splitting the Sample

\begin{tabular}{|c|c|c|c|c|c|c|}
\hline & (1) & $(2)$ & (3) & $(4)$ & $(5)$ & (6) \\
\hline & \multicolumn{2}{|c|}{ Non-OECD } & \multicolumn{2}{|c|}{ Initial Democracies } & \multicolumn{2}{|c|}{ From 1960 onward } \\
\hline & OLS & 2SLS & OLS & 2SLS & OLS & 2SLS \\
\hline \multirow[t]{2}{*}{ log(integration_demo) } & $1.499^{* *}$ & $4.977^{* * *}$ & 0.682 & -2.365 & $1.898^{* * *}$ & $3.680^{* *}$ \\
\hline & $(0.570)$ & $(1.418)$ & $(0.571)$ & $(2.144)$ & $(0.537)$ & $(1.411)$ \\
\hline \multirow[t]{2}{*}{$\log ($ integration_auto) } & $-0.790 * * *$ & -0.828 & -0.175 & -0.928 & $-0.669^{* *}$ & -0.527 \\
\hline & $(0.292)$ & $(0.717)$ & $(0.332)$ & $(1.082)$ & $(0.277)$ & $(0.626)$ \\
\hline Observations & 856 & 856 & 591 & 591 & 1,104 & 1,104 \\
\hline Number of countries & 89 & 89 & 60 & 60 & 116 & 116 \\
\hline F-stat for weak Ivs & & 8.464 & & 9.461 & & 7.625 \\
\hline AP F-stat for log(integration_demo) & & 9.709 & & 10.039 & & 9.937 \\
\hline AP F-stat for log(integration_auto) & & 42.559 & & 20.747 & & 48.525 \\
\hline \multicolumn{7}{|c|}{$\begin{array}{l}\text { Notes: The dependent variable is Polity2. Columns 1-2 and 3-4 restrict the sample to non-OECD members and to countries with baseline Polity2 } \\
\text { score strictly positive, respectively. Columns 5-6 consider only years from } 1960 \text { (included) onwards. The main regressors of interest are (log) } \\
\text { trade with democratic and autocratic partners divided by GDP. Actual trade is instrumented with predicted trade as described in the main text } \\
\text { (see Sections } 2.1 \text { and } 2.2 \text { ), where democratic (autocratic) partners are defined as partners with Polity2 score five years before strictly positive } \\
\text { (non-positive). All regressions are estimated using 5-year intervals. The sample in columns 1-4 covers the period 1955-2010 (included), the one } \\
\text { in columns 5-6 is for 1960-2010 (included). All regressions include year and country fixed effects. AP F-stat refers to the (robust) F-stat for the } \\
\text { Angrist and Pischke weak identification test for each individual endogenous regressor. The F-stat for weak IVs is the Kleibergen-Paap Wald rk } \\
\text { statistics for (jointly) weak instruments. Standard errors (reported in parentheses) are clustered at the country level, and the ones for } 2 \mathrm{SLS} \text { are } \\
\text { corrected to account for the fact that the instruments depend on the (estimated) parameters of the bilateral trade equation; }{ }^{* * *} p<0.01,{ }^{* *} \\
p<0.05,{ }^{*} p<0.1\end{array}$} \\
\hline
\end{tabular}




\begin{tabular}{|c|c|c|c|c|}
\hline & (1) & $(2)$ & $(3)$ & $(4)$ \\
\hline & 2SLS & 2SLS & 2SLS & 2SLS \\
\hline \multirow[t]{2}{*}{ log(integration_demo) } & $5.021^{* * *}$ & 0.775 & 2.621 & 2.077 \\
\hline & $(1.561)$ & $(1.775)$ & $(1.725)$ & $(2.259)$ \\
\hline \multirow{2}{*}{$\log (\text { integration_demo })^{*}($ Num. Tel. Lines $)$} & $-0.504^{* * *}$ & & & \\
\hline & $(0.121)$ & & & \\
\hline \multirow[t]{2}{*}{$\log ($ integration_demo)*(Baseline Polity2) } & & $-0.870^{* * *}$ & & \\
\hline & & $(0.148)$ & & \\
\hline \multirow[t]{2}{*}{$\log ($ integration_demo $) *($ RQ polariz Index $)$} & & & $-3.349^{*}$ & \\
\hline & & & $(1.709)$ & \\
\hline \multirow[t]{2}{*}{$\log ($ integration_demo $) * 1($ State religion 1900$)$} & & & & 2.469 \\
\hline & & & & $(2.242)$ \\
\hline Observations & 1,049 & 1,152 & 1,121 & 1,152 \\
\hline Number of countries & 116 & 116 & 112 & 116 \\
\hline F-stat for weak IV & 3.675 & 4.204 & 3.791 & 4.148 \\
\hline AP F-stat for log(integration_demo) & 6.689 & 6.228 & 5.944 & 7.818 \\
\hline AP F-stat for interaction with log(integration_demo) & 13.036 & 20.582 & 12.393 & 11.884 \\
\hline
\end{tabular}

Notes: The dependent variable is Polity2. The main regressors of interest are $(\log )$ trade with democratic partners divided by GDP and its interaction with, respectively: i) the number of telephone lines per 100 people at baseline (column 1); ii) baseline Polity 2 (column 2); iii) the Montalvo and Reynal-Querol (2005) index of polarization, standardised to have zero mean and standard deviation equal to 1 (column 3); and iv) a dummy for the presence of state religion in 1900 from Barro and McCleary (2005). Actual trade is instrumented with predicted trade as described in the main text (see Sections 2.1 and 2.2). All regressions always include the log of trade with autocratic partners divided by GDP and its interaction with variables (i)-(iv) above (coefficients on these variables not shown for brevity). Democratic (autocratic) partners are defined as partners with Polity2 score five years before strictly positive (non-positive). All regressions are estimated on 1955-2010 data at 5-year frequency, and include year and country fixed effects. AP F-stat refers to the (robust) F-stat for the Angrist and Pischke weak identification test for log trade with democratic partners (divided by GDP) and its interaction. The AP F-stats for trade with democratic partners and its interactions are not reported for brevity. The F-stat for weak IVs is the Kleibergen-Paap Wald rk statistics for (jointly) weak instruments. Standard errors (reported in parentheses) are clustered at the country level and are corrected to account for the fact that the instruments depend on the (estimated) parameters of the bilateral trade equation; $* * * p<0.01,{ }^{* *} p<0.05,{ }^{*} p<0.1$ 
Figure 1: Change in the Elasticity of Trade with Respect to Air and Sea Distances (Country-Year and Country-Pair Fixed Effects)

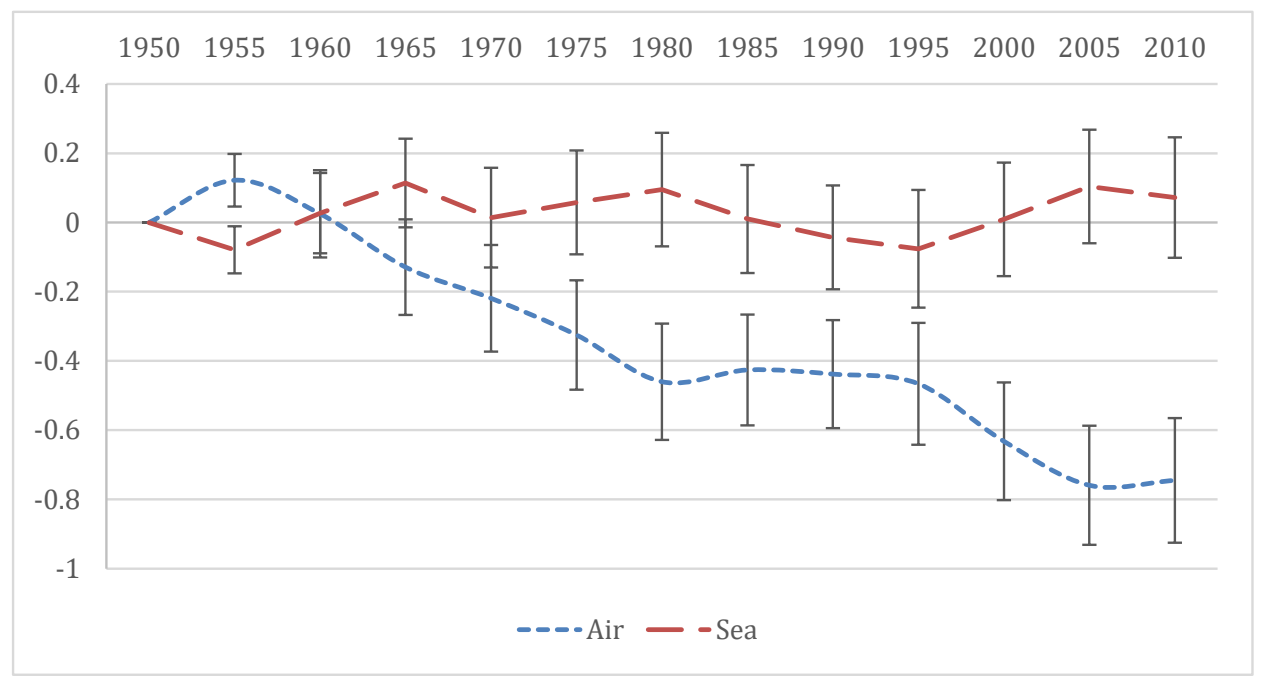

Notes: Estimated coefficients for specification (2) (also reported in column 1 of Table A2). Error Bars are plus and minus two standard errors, clustered at the country-pair and year level.

Figure 2: First Stage for Main Specification
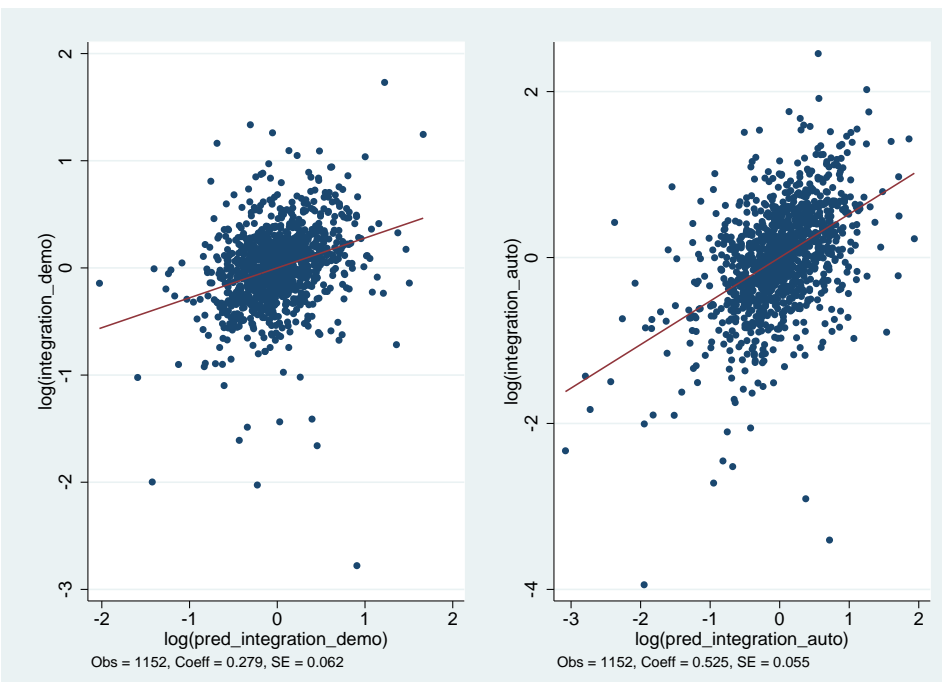

Notes: These graphs correspond to the First Stage regressions reported in column 4, Panels C and D of Table 2. All variables are partialled out of fixed effects and other regressors. Standard errors are clustered at the country level and corrected to account for the fact that the instruments depend on the (estimated) parameters of the bilateral trade equation. 
Figure 3: Reduced Form for Main Specification
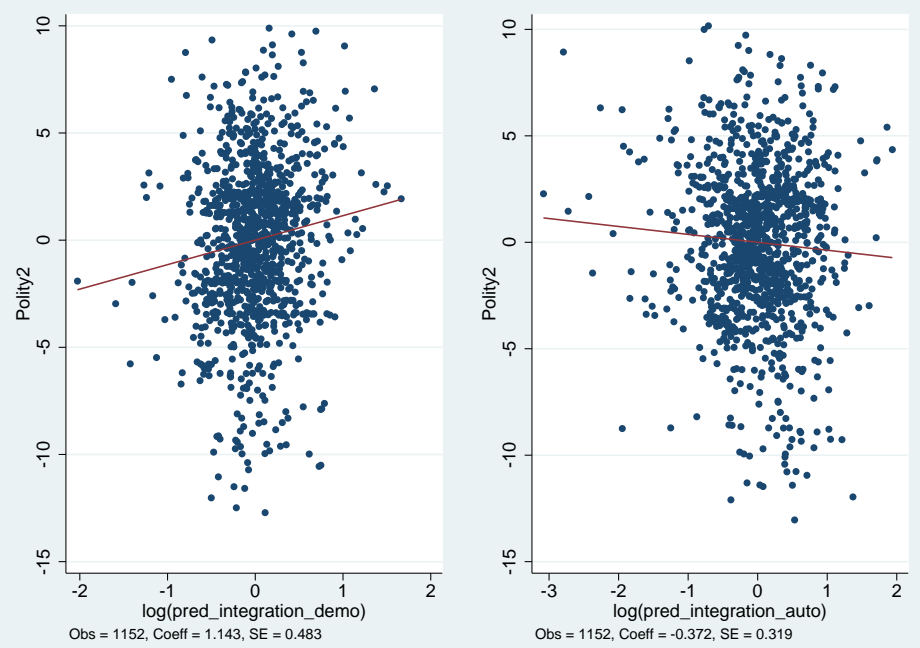

Notes: These graphs correspond to the Reduced Form regression for the specification in column 4, Panel A, of Table 2 (reported in column 2 of Table A3). All variables are partialled out of fixed effects and other regressors. Standard errors are clustered at the country level and corrected to account for the fact that the instruments depend on the (estimated) parameters of the bilateral trade equation. 


\section{Appendix}

Table A1: Variables Definition and Sources

\begin{tabular}{|c|c|c|}
\hline VARIABLE & DESCRIPTION & SOURCE \\
\hline Polity2 & $\begin{array}{l}\text { Annual democracy score, taking on discrete values from -10 (full autoc- } \\
\text { racy) to } 10 \text { (full democracy) }\end{array}$ & $\begin{array}{l}\text { Polity IV Project } \\
\text { dataset }\end{array}$ \\
\hline Dpolity & Dummy equal to 1 if Polity $2>0$, and equal to 0 otherwise & Authors' calculations \\
\hline Demo_FH & $\begin{array}{l}\text { Dummy equal to } 1 \text { if the Freedom Rating is greater or equal than } 4 . \\
\text { Freedom Rating is the average of the variables political rights and civil } \\
\text { liberty, both measured on a } 1-7 \text { scale, with } 7 \text { corresponding to highest } \\
\text { level of freedom (Note that we inverted the original Freedom House scale) }\end{array}$ & $\begin{array}{l}\text { Authors' calculations } \\
\text { based on Freedom } \\
\text { House data }\end{array}$ \\
\hline Trade & $\begin{array}{l}\text { Sum of annual bilateral trade flows for each country i over all trade part- } \\
\text { ners } \mathrm{j} \text { for which we have predicted trade from the gravity equation. Bi- } \\
\text { lateral trade flows are calculated as the average of the two trade flows in } \\
\text { merchandise goods from country } i \text { to } j \text {, and from } j \text { to i. These two flows, } \\
\text { in turn, are obtained as the average of the proper directional flows. E.g., } \\
\text { the flow from } i \text { to } j \text { is the mean of imports of country j from i and export } \\
\text { of } i \text { to } j \text {. The latter two figures are usually not identical because of differ- } \\
\text { ences in the exact definition of imports (mostly CIF) and exports (mostly } \\
\text { FOB) and in each country's reporting. All trade data are measured at } \\
\text { current million US\$ }\end{array}$ & $\begin{array}{l}\text { Authors' calcula- } \\
\text { tions from IMF DoT } \\
\text { dataset }\end{array}$ \\
\hline GDP & Output-side GDP at current million US\$ & Penn World Table 9.0 \\
\hline rGDP & Output-side GDP at chained PPPs in millions of 2005 US\$ & Penn World Table 9.0 \\
\hline Population & Population in the country, in millions & Penn World Table 9.0 \\
\hline Integration & $\begin{array}{l}\text { Trade over GDP } \\
\text { Penn World Table } 9.0\end{array}$ & Authors' calculations \\
\hline Integration demo & $\begin{array}{l}\text { Trade with democratic partners over GDP. Trade with democratic part- } \\
\text { ners is obtained by summing bilateral trade flows with partners whose } \\
\text { Polity } 2 \text { score is strictly positive and for which we have predicted trade } \\
\text { from the gravity equation. }\end{array}$ & Authors' calculations \\
\hline Integration auto & $\begin{array}{l}\text { Trade with autocratic partners over GDP. Trade with autocratic partners } \\
\text { is obtained by summing bilateral trade flows with partners whose Polity } 2 \\
\text { score is negative and for which we have predicted trade from the gravity } \\
\text { equation }\end{array}$ & Authors' calculations \\
\hline Pred integration & $\begin{array}{l}\text { Predicted trade over GDP. Predicted trade is derived from a gravity equa- } \\
\text { tion as explained in the main text (Section } 2.1 \text { ) }\end{array}$ & Authors' calculations \\
\hline $\begin{array}{l}\text { Pred integration } \\
\text { demo }\end{array}$ & $\begin{array}{l}\text { Predicted trade with democracies over GDP. Predicted trade with democ- } \\
\text { racies is derived from a gravity equation as explained in the main text } \\
\text { (Sections } 2.1 \text { and } 2.3 \text { ). Democracies are defined with a } 5 \text {-year lag }\end{array}$ & Authors' calculations \\
\hline $\begin{array}{l}\text { Pred integration } \\
\text { auto }\end{array}$ & $\begin{array}{l}\text { Predicted trade with autocracies over GDP. Predicted trade with autoc- } \\
\text { racies is derived from a gravity equation as explained in the main text } \\
\text { (Sections } 2.1 \text { and } 2.3 \text { ). Autocracies are defined with a } 5 \text {-year lag }\end{array}$ & Authors' calculations \\
\hline Air Distance & Great circle distances (in $\mathrm{km}$ ) between the 25 main cities in each country & CEPII dataset \\
\hline
\end{tabular}




\section{Table A1 Cont'd: Variables Definition and Sources}

\begin{tabular}{|c|c|c|}
\hline VARIABLE & DESCRIPTION & SOURCE \\
\hline Sea Distance & $\begin{array}{l}\text { Distance between the two main commercial ports for each pair of countries } \\
\text { (in } \mathrm{km} \text { ). See main text for details }\end{array}$ & Vesseldistance.org \\
\hline Colonial Tie & Dummy equal to 1 if pair of countries ever in colonial relationship & CEPII dataset \\
\hline Common Language & $\begin{array}{l}\text { Dummy equal to } 1 \text { if a language is spoken by at least } 9 \% \text { of the population } \\
\text { in both countries }\end{array}$ & CEPII dataset \\
\hline Common Border & Dummy equal to 1 if pair of countries share a common border. & CEPII dataset \\
\hline Demo_wave & $\begin{array}{l}\text { Share of democracies in each country's "influence set". See main text at } \\
\text { Section } 3.2 .1 \text { and Acemoglu et al. (2015) for details. }\end{array}$ & $\begin{array}{l}\text { Authors' calculations } \\
\text { based on Acemoglu et } \\
\text { al. (2015) }\end{array}$ \\
\hline $\begin{array}{l}\text { Percentage of sec- } \\
\text { ondary complete }\end{array}$ & Fraction of the population with completed secondary schooling & Barro and Lee(2013) \\
\hline Years of schooling & Average years of schooling in the population & Barro and Lee(2013) \\
\hline $\begin{array}{l}\text { Number of Tele- } \\
\text { phone Lines per } \\
100 \text { People }\end{array}$ & $\begin{array}{l}\text { Number of fixed telephone lines that connect a subscribers terminal equip- } \\
\text { ment to the public switched telephone network and that have a port on } \\
\text { a telephone exchange per people. Measured at baseline }\end{array}$ & $\begin{array}{l}\text { World Bank, World } \\
\text { Development Indica- } \\
\text { tors }\end{array}$ \\
\hline State religion & Dummy indicator for the presence of state religion in 1900 & $\begin{array}{l}\text { Barro and McCleary } \\
(2005)\end{array}$ \\
\hline Rq polariz & Montalvo and Reynal-Querol (2005) polarization index & $\begin{array}{l}\text { Montalvo and } \\
\text { Reynal-Querol (2005) }\end{array}$ \\
\hline Service exporter & $\begin{array}{l}\text { Dummy equal to } 1 \text { if the country is an exporter of services. Measured at } \\
\text { baseline }\end{array}$ & $\begin{array}{l}\text { World Bank Indica- } \\
\text { tors }\end{array}$ \\
\hline Agric. Land & Fraction of land devoted to agriculture & $\begin{array}{l}\text { World Bank Indica- } \\
\text { tors }\end{array}$ \\
\hline $\begin{array}{l}\text { Industry value } \\
\text { added }\end{array}$ & Value added from industry. Measured at baseline & $\begin{array}{l}\text { World Bank Indica- } \\
\text { tors }\end{array}$ \\
\hline Agric. value added & Value added from agriculture. Measured at baseline & $\begin{array}{l}\text { World Bank Indica- } \\
\text { tors }\end{array}$ \\
\hline Minerals & Number of minerals in the country & Parker (1997) \\
\hline
\end{tabular}


Table A2: Gravity Equation Coefficients

\begin{tabular}{|c|c|c|}
\hline & (1) & $(2)$ \\
\hline $\log ($ air $) \times 1950$ & & $\begin{array}{c}-0.342^{* * *} \\
(0.066)\end{array}$ \\
\hline $\log ($ air $) \times 1955$ & $\begin{array}{c}0.122^{* * *} \\
(0.038)\end{array}$ & $\begin{array}{c}-0.289^{* * *} \\
(0.075)\end{array}$ \\
\hline $\log ($ air $) \times 1960$ & $\begin{array}{c}0.025 \\
(0.063)\end{array}$ & $\begin{array}{c}-0.420^{* * *} \\
(0.065)\end{array}$ \\
\hline $\log ($ air $) \times 1965$ & $\begin{array}{l}-0.129 * \\
(0.069)\end{array}$ & $\begin{array}{c}-0.535^{* * *} \\
(0.065)\end{array}$ \\
\hline $\log ($ air $) \times 1970$ & $\begin{array}{c}-0.219^{* * *} \\
(0.077)\end{array}$ & $\begin{array}{c}-0.665^{* * *} \\
(0.072)\end{array}$ \\
\hline $\log ($ air $) \times 1975$ & $\begin{array}{c}-0.325^{* * *} \\
(0.079)\end{array}$ & $\begin{array}{c}-0.836^{* * *} \\
(0.075)\end{array}$ \\
\hline $\log ($ air $) x 1980$ & $\begin{array}{c}-0.460^{* * *} \\
(0.084)\end{array}$ & $\begin{array}{c}-0.966^{* * *} \\
(0.082)\end{array}$ \\
\hline $\log ($ air $) \times 1985$ & $\begin{array}{c}-0.426^{* * *} \\
(0.080)\end{array}$ & $\begin{array}{c}-0.933^{* * *} \\
(0.068)\end{array}$ \\
\hline $\log ($ air $) \times 1990$ & $\begin{array}{c}-0.438^{* * *} \\
(0.078)\end{array}$ & $\begin{array}{c}-0.937^{* * *} \\
(0.063)\end{array}$ \\
\hline $\log ($ air $) \times 1995$ & $\begin{array}{c}-0.466^{* * *} \\
(0.088)\end{array}$ & $\begin{array}{c}-0.954^{* * *} \\
(0.064)\end{array}$ \\
\hline $\log ($ air $) \times 2000$ & $\begin{array}{c}-0.632^{* * *} \\
(0.085)\end{array}$ & $\begin{array}{c}-1.116^{* * *} \\
(0.061)\end{array}$ \\
\hline $\log ($ air $) \times 2005$ & $\begin{array}{c}-0.759^{* * *} \\
(0.086)\end{array}$ & $\begin{array}{c}-1.264^{* * *} \\
(0.063)\end{array}$ \\
\hline $\log ($ air $) x 2010$ & $\begin{array}{c}-0.745^{* * *} \\
(0.090)\end{array}$ & $\begin{array}{c}-1.235^{* * *} \\
(0.063)\end{array}$ \\
\hline $\log ($ sea $) \times 1950$ & & $\begin{array}{c}-0.395^{* * *} \\
(0.063)\end{array}$ \\
\hline $\log ($ sea $) \times 1955$ & $\begin{array}{c}-0.079 * * \\
(0.034)\end{array}$ & $\begin{array}{c}-0.445^{* * *} \\
(0.071)\end{array}$ \\
\hline $\log ($ sea $) \times 1960$ & $\begin{array}{c}0.027 \\
(0.058)\end{array}$ & $\begin{array}{c}-0.316^{* * *} \\
(0.063)\end{array}$ \\
\hline $\log ($ sea $) \times 1965$ & $\begin{array}{l}0.114^{*} \\
(0.064)\end{array}$ & $\begin{array}{c}-0.325^{* * *} \\
(0.064)\end{array}$ \\
\hline $\log ($ sea $) \times 1970$ & $\begin{array}{c}0.014 \\
(0.072)\end{array}$ & $\begin{array}{c}-0.489^{* * *} \\
(0.069)\end{array}$ \\
\hline $\log ($ sea $) \times 1975$ & $\begin{array}{c}0.058 \\
(0.075)\end{array}$ & $\begin{array}{c}-0.400^{* * *} \\
(0.072)\end{array}$ \\
\hline $\log ($ sea $) \times 1980$ & $\begin{array}{c}0.095 \\
(0.082)\end{array}$ & $\begin{array}{c}-0.380^{* * *} \\
(0.084)\end{array}$ \\
\hline $\log ($ sea $) \times 1985$ & 0.010 & $-0.482^{* * *}$ \\
\hline
\end{tabular}


Table A2 Cont'd: Gravity Equation Coefficients

\begin{tabular}{ccc}
\hline & $(1)$ & $(2)$ \\
\hline & $(0.078)$ & $(0.069)$ \\
$\log ($ sea $) \times 1990$ & -0.043 & $-0.586^{* * *}$ \\
& $(0.075)$ & $(0.065)$ \\
$\log ($ sea $) \times 1995$ & -0.076 & $-0.662^{* * *}$ \\
& $(0.085)$ & $(0.064)$ \\
$\log ($ sea $) \times 2000$ & 0.009 & $-0.590^{* * *}$ \\
& $(0.082)$ & $(0.062)$ \\
$\log ($ sea $) \times 2005$ & 0.104 & $-0.482^{* * *}$ \\
& $(0.082)$ & $(0.062)$ \\
$\log$ (sea)x2010 & 0.072 & $-0.539^{* * *}$ \\
& $(0.087)$ & $(0.061)$ \\
& & \\
Observations & 369,820 & 370,101 \\
\hline
\end{tabular}

Notes: The dependent variable is (log) trade. Column 1 reports estimates of equation (2). It includes origin and destination country-time fixed effects and country-pair fixed effects. Column 2 reports estimates of equation (3). It includes origin and destination country-time fixed effects, as well as variables for country-pairs sharing a border, common language or colonial origins. The coefficients of interest are the elasticities with respect to air and sea distance, which are allowed to vary every 5-year period. Data are annual, and cover the period 1950-2014. Robust standard errors, clustered at the pair-year level, reported in parentheses; ${ }^{* * *} p<0.01,{ }^{* *} p<0.05,{ }^{*} p<0.1$ 
Table A3: Economic Integration and Democracy: Reduced-Form

\begin{tabular}{lccccc}
\hline & $(1)$ & $(2)$ & $(3)$ & $(4)$ & $(5)$ \\
VARIABLES & Polity2 & Polity2 & Polity2 & Polity2 & Polity2 \\
\hline & & & & & \\
$\log$ (pred_integration) & 0.714 & & & & \\
& $(0.445)$ & & & & \\
$\log$ (pred_integration_demo) & & $1.143^{* *}$ & $1.003^{* *}$ & $1.208^{* *}$ & $1.052^{* * *}$ \\
& & $(0.483)$ & $(0.431)$ & $(0.480)$ & $(0.382)$ \\
$\log$ (pred_integration_auto) & & -0.372 & -0.075 & -0.512 & $-0.530^{*}$ \\
& & $(0.319)$ & $(0.291)$ & $(0.318)$ & $(0.300)$ \\
& & & & & \\
Observations & 1,152 & 1,152 & 1,152 & 1,152 & 1,152 \\
Number of countries & 116 & 116 & 116 & 116 & 116 \\
\hline
\end{tabular}

Notes: Reduced-form regressions corresponding to columns 2 and 4-7 in Table 2. The dependent variable is Polity2. The main regressors of interest are predicted trade over GDP, considered together in column 1 and separately for democratic and autocratic partners in columns 2-5. Predicted trade is constructed as described in the main text (see Sections 2.1 and 2.2), where democratic (autocratic) partners are defined as partners with Polity2 score five years before strictly positive (non-positive). Column 3 controls for demo_wave. Columns 4 and 5 include interactions between year dummies and dummies for non-OECD country, and baseline nondemocracy, respectively. All regressions are estimated on 1955-2010 data at 5-year frequency, and include year and country fixed effects. Standard errors (reported in parentheses) are clustered at the country level and corrected to account for the fact that the instruments depend on the (estimated) parameters of the bilateral trade equation; ${ }^{* * *} p<0.01,{ }^{* *} p<0.05,{ }^{*} p<0.1$ 
Table A4: Economic Integration and Democracy: Alternative IV

\begin{tabular}{|c|c|c|c|c|c|c|c|}
\hline & (1) & $(2)$ & (3) & (4) & (5) & $(6)$ & $(7)$ \\
\hline & OLS & 2SLS & OLS & 2SLS & 2SLS & 2SLS & 2SLS \\
\hline \multicolumn{8}{|c|}{ PANEL A - OLS and SECOND STAGE: dep var is Polity2 } \\
\hline \multirow[t]{2}{*}{$\log ($ integration $)$} & $1.155^{* *}$ & 3.136 & & & & & \\
\hline & $(0.558)$ & $(2.394)$ & & & & & \\
\hline \multirow[t]{2}{*}{$\log ($ integration_demo) } & & & $1.693^{* * *}$ & $3.843^{* *}$ & 2.973 & $3.149^{*}$ & $2.884^{*}$ \\
\hline & & & $(0.552)$ & $(1.808)$ & $(1.802)$ & $(1.646)$ & $(1.730)$ \\
\hline \multirow[t]{2}{*}{$\log ($ integration_auto) } & & & $-0.551^{* *}$ & -0.504 & 0.226 & -0.870 & -0.886 \\
\hline & & & $(0.267)$ & $(0.716)$ & $(0.629)$ & $(0.686)$ & $(0.640)$ \\
\hline F-stat for weak IVs & & 13.436 & & 9.215 & 8.892 & 10.383 & 8.949 \\
\hline \multicolumn{8}{|c|}{ PANEL B - FIRST STAGE: dep var is log(integration) } \\
\hline \multirow[t]{2}{*}{$\log$ (pred_integration) } & & $0.156^{* * *}$ & & & & & \\
\hline & & $(0.043)$ & & & & & \\
\hline \multicolumn{8}{|c|}{ PANEL C - FIRST STAGE: dep var is $\log$ (integration_demo) } \\
\hline \multirow[t]{2}{*}{$\log ($ pred_integration_demo $)$} & & & & $0.153^{* * *}$ & $0.148^{* * *}$ & $0.161^{* * *}$ & $0.152^{* * *}$ \\
\hline & & & & $(0.034)$ & $(0.034)$ & $(0.034)$ & $(0.034)$ \\
\hline \multirow[t]{2}{*}{$\log ($ pred_integration_auto) } & & & & 0.024 & 0.029 & 0.035 & 0.020 \\
\hline & & & & $(0.022)$ & $(0.021)$ & $(0.022)$ & $(0.023)$ \\
\hline \multicolumn{3}{|l|}{ AP F-stat for $\log$ (integration_demo) } & & 10.588 & 9.710 & 11.576 & 10.579 \\
\hline \multicolumn{8}{|c|}{ PANEL D - FIRST STAGE: dep var is log(integration_auto) } \\
\hline \multirow[t]{2}{*}{$\log ($ pred_integration_demo) } & & & & -0.025 & -0.030 & -0.031 & -0.025 \\
\hline & & & & $(0.047)$ & $(0.046)$ & $(0.046)$ & $(0.047)$ \\
\hline \multirow[t]{2}{*}{$\log$ (pred_integration_auto) } & & & & $0.237^{* * *}$ & $0.241^{* * *}$ & $0.236^{* * *}$ & $0.235^{* * *}$ \\
\hline & & & & $(0.028)$ & $(0.028)$ & $(0.031)$ & $(0.030)$ \\
\hline AP F-stat for log(integration_auto) & & & & 38.076 & 42.713 & 31.719 & 35.623 \\
\hline Observations & 1,192 & 1,192 & 1,192 & 1,192 & 1,192 & 1,192 & 1,192 \\
\hline Number of countries & 116 & 116 & 116 & 116 & 116 & 116 & 116 \\
\hline
\end{tabular}

Notes:The dependent variable is reported at the top of each Panel. The main regressor of interest in Panel A is (log) trade over GDP, considered together in columns 1-2 and separately for democratic and autocratic partners in columns 3-7. Actual trade is instrumented with predicted trade as described in the main text, relying on the gravity specification (3) (see Sections 2.1 and 2.2), where democratic (autocratic) partners are defined as partners with Polity2 score five years before strictly positive (non-positive). Column 5 controls for demo_wave. Columns 6 and 7 include interactions between year dummies and dummies for non-OECD country, and baseline non-democracy, respectively. All regressions are estimated on 1950-2010 data at 5-year frequency, and include year and country fixed effects. AP F-stat refers to the (robust) F-stat for the Angrist and Pischke weak identification test for each individual endogenous regressor. The F-stat for weak IVs is the Kleibergen-Paap Wald rk statistics for (jointly) weak instruments. Standard errors (reported in parentheses) are clustered at the country level, and the ones for 2SLS and First Stages are corrected to account for the fact that the instruments depend on the (estimated) parameters of the bilateral trade equation; ${ }^{* * *} p<0.01,{ }^{* *} p<0.05,{ }^{*} p<0.1$ 
Table A5: Economic Integration and Democracy: Poisson Pseudo-Maximum Likelihood

\begin{tabular}{|c|c|c|c|c|c|c|}
\hline VARIABLES & $\begin{array}{c}(1) \\
\text { OLS }\end{array}$ & $\begin{array}{c}(2) \\
2 \text { SLS ols }\end{array}$ & $\begin{array}{c}(3) \\
\text { 2SLS ppml }\end{array}$ & $\begin{array}{c}(4) \\
\text { OLS }\end{array}$ & $\begin{array}{c}(5) \\
2 \text { SLS ols }\end{array}$ & $\begin{array}{c}(6) \\
\text { 2SLS ppm }\end{array}$ \\
\hline \multicolumn{7}{|c|}{ PANEL A - OLS and SECOND STAGE: dep var is Polity2 } \\
\hline $\log ($ integration_demo $)$ & $\begin{array}{c}1.710^{* * *} \\
(0.550)\end{array}$ & $\begin{array}{c}4.243^{* * *} \\
(1.527)\end{array}$ & $\begin{array}{c}5.527^{* * *} \\
(2.056)\end{array}$ & $\begin{array}{c}1.693^{* * *} \\
(0.552)\end{array}$ & $\begin{array}{l}4.099 * * \\
(1.802)\end{array}$ & $\begin{array}{c}5.567^{* * * *} \\
(2.093)\end{array}$ \\
\hline $\log ($ integration_auto) & $\begin{array}{c}-0.594^{* *} \\
(0.270)\end{array}$ & $\begin{array}{l}-1.084^{*} \\
(0.594)\end{array}$ & $\begin{array}{c}-1.385^{*} \\
(0.763)\end{array}$ & $\begin{array}{c}-0.551^{* *} \\
(0.267)\end{array}$ & $\begin{array}{l}-0.820 \\
(0.702)\end{array}$ & $\begin{array}{l}-1.162 \\
(0.785)\end{array}$ \\
\hline F-stat for weak IVs & & 7.349 & 4.963 & & 9.515 & 5.959 \\
\hline \multicolumn{7}{|c|}{ PANEL B - FIRST STAGE: dep var is log(integration_demo) } \\
\hline $\log ($ pred_integration_demo) & & $\begin{array}{c}0.290^{* * *} \\
(0.068)\end{array}$ & $\begin{array}{c}0.286^{* * *} \\
(0.080)\end{array}$ & & $\begin{array}{c}0.158^{* * *} \\
(0.036)\end{array}$ & $\begin{array}{c}0.198^{* * *} \\
(0.053)\end{array}$ \\
\hline $\log$ (pred_integration_auto) & & $\begin{array}{l}-0.033 \\
(0.047)\end{array}$ & $\begin{array}{l}-0.078 \\
(0.064)\end{array}$ & & $\begin{array}{c}0.023 \\
(0.022)\end{array}$ & $\begin{array}{l}-0.022 \\
(0.035)\end{array}$ \\
\hline AP F-stat for log(integration_demo) & & 9.221 & 6.628 & & 10.026 & 7.219 \\
\hline \multicolumn{7}{|c|}{ PANEL C - FIRST STAGE: dep var is log(integration_auto) } \\
\hline $\log ($ pred_integration_demo) & & $\begin{array}{c}-0.363^{* * *} \\
(0.111)\end{array}$ & $\begin{array}{c}-0.399^{* * *} \\
(0.129)\end{array}$ & & $\begin{array}{c}0.016 \\
(0.049)\end{array}$ & $\begin{array}{l}-0.048 \\
(0.086)\end{array}$ \\
\hline $\log$ (pred_integration_auto) & & $\begin{array}{c}0.617^{* * *} \\
(0.063)\end{array}$ & $\begin{array}{c}0.661^{* * *} \\
(0.079)\end{array}$ & & $\begin{array}{c}0.253^{* * *} \\
(0.029)\end{array}$ & $\begin{array}{c}0.339^{* * *} \\
(0.042)\end{array}$ \\
\hline AP F-stat for log(integration_auto) & & 52.432 & 35.350 & & 40.084 & 33.517 \\
\hline Observations & 1,152 & 1,152 & 1,152 & 1,192 & 1,192 & 1,192 \\
\hline Number of countries & 116 & 116 & 116 & 116 & 116 & 116 \\
\hline
\end{tabular}

Notes: The dependent variable is reported at the top of each Panel. Columns 1 and 4 are the OLS estimates of (6) over the same samples as in columns 2-3 and 5-6, respectively. Columns 2-3 and 5-6 report 2SLS estimates where actual trade is instrumented with predicted trade derived as described in the main text (see Sections 2.1 and 2.2), though relying on simplified versions of the gravity equation (see the end of Section 3.3). In particular, estimates in columns 2-3 are derived from a gravity specification with distances and fixed effects for country-pair and time. In columns 5 and 6 , the gravity equation includes distances, variables for common border, common language, and common colonial history, plus fixed effects for origin, destination and time. In columns 2 and 5, those gravity equations are estimated with OLS. In columns 3 and 6, with PPML. All regressions are estimated on 1955-2010 data at 5-year frequency, and include country and time fixed effects. AP F-stat refers to the (robust) F-stat for the Angrist and Pischke weak identification test for each individual endogenous regressor. The F-stat for weak IVs is the Kleibergen-Paap Wald rk statistics for (jointly) weak instruments. Standard errors (reported in parentheses) are clustered at the country level, and the ones in columns 2,3 , and 5 are corrected to account for the fact that the instruments depend on the (estimated) parameters of the bilateral trade equation; ${ }^{* * *} p<0.01,{ }^{* *} p<0.05,{ }^{*} p<0.1$ 
Table A6: Sample Composition over Time

\begin{tabular}{lcccc}
\hline & 1955 & 1960 & 1970 & 1980 \\
\hline Mean Polity2 & 2.896 & 1.803 & -0.478 & -0.903 \\
Median Polity2 & 5 & 4.5 & -2 & -5 \\
Num. Countries & 48 & 66 & 92 & 103 \\
Num. Baseline Demo & 30 & 34 & 42 & 44 \\
Num. Baseline Auto & 18 & 32 & 50 & 60 \\
\hline
\end{tabular}


Table A7: Periods in Main Sample for each Country

\begin{tabular}{|c|c|c|c|}
\hline Country & Time Periods & Country & Time Periods \\
\hline ALBANIA & 9 & KENYA & 10 \\
\hline ALGERIA & 10 & KOREA SOUTH & 12 \\
\hline ANGOLA & 8 & KUWAIT & 8 \\
\hline ARGENTINA & 12 & LATVIA & 4 \\
\hline AUSTRALIA & 12 & LEBANON & 6 \\
\hline BAHRAIN & 8 & LIBERIA & 10 \\
\hline BANGLADESH & 8 & LITHUANIA & 4 \\
\hline BELGIUM & 3 & MADAGASCAR & 11 \\
\hline BELGIUM AND LUXEMBOURG & 9 & MALAYSIA & 9 \\
\hline BENIN & 10 & MAURITANIA & 11 \\
\hline BRAZIL & 12 & MAURITIUS & 9 \\
\hline BULGARIA & 9 & MEXICO & 12 \\
\hline CAMBODIA & 7 & MOROCCO & 11 \\
\hline CAMEROON & 11 & MOZAMBIQUE & 8 \\
\hline CANADA & 12 & MYANMAR & 10 \\
\hline CAPE VERDE & 8 & NAMIBIA & 5 \\
\hline CHILE & 12 & NETHERLANDS & 12 \\
\hline CHINA & 12 & NEW ZEALAND & 12 \\
\hline COLOMBIA & 12 & NICARAGUA & 12 \\
\hline COMOROS & 8 & NIGERIA & 11 \\
\hline CONGO & 10 & NORWAY & 12 \\
\hline COSTA RICA & 12 & OMAN & 9 \\
\hline CROATIA & 4 & PAKISTAN & 12 \\
\hline CYPRUS & 11 & PANAMA & 12 \\
\hline DEM REP CONGO & 11 & PERU & 12 \\
\hline DENMARK & 12 & PHILIPPINES & 12 \\
\hline DJIBOUTI & 7 & POLAND & 9 \\
\hline DOMINICAN REP & 12 & PORTUGAL & 12 \\
\hline ECUADOR & 12 & QATAR & 8 \\
\hline EGYPT & 12 & ROMANIA & 11 \\
\hline EL SALVADOR & 12 & RUSSIA & 4 \\
\hline EQUATORIAL GUINEA & 9 & SAUDI ARABIA & 9 \\
\hline ESTONIA & 4 & SENEGAL & 11 \\
\hline FIJI & 9 & SERBIA & 4 \\
\hline FINLAND & 12 & SIERRA LEONE & 10 \\
\hline FRANCE & 12 & SINGAPORE & 10 \\
\hline GABON & 11 & SLOVENIA & 4 \\
\hline GAMBIA & 10 & SOUTH AFRICA & 12 \\
\hline GEORGIA & 4 & SPAIN & 12 \\
\hline GERMANY & 12 & SRI LANKA & 12 \\
\hline GHANA & 11 & SUDAN & 9 \\
\hline GREECE & 12 & SURINAME & 8 \\
\hline GUATEMALA & 12 & SWEDEN & 12 \\
\hline GUINEA & 11 & SYRIA & 10 \\
\hline GUINEA-BISSAU & 8 & TANZANIA & 10 \\
\hline HAITI & 11 & THAILAND & 12 \\
\hline HONDURAS & 12 & TOGO & 10 \\
\hline INDIA & 12 & TRINIDAD AND TOBAGO & 10 \\
\hline INDONESIA & 11 & TUNISIA & 11 \\
\hline IRAN & 12 & TURKEY & 12 \\
\hline IRAQ & 8 & UKRAINE & 4 \\
\hline IRELAND & 12 & UNITED ARAB EMIRATES & 8 \\
\hline ISRAEL & 12 & UNITED KINGDOM & 12 \\
\hline ITALY & 12 & UNITED STATES & 12 \\
\hline IVORY COAST & 11 & URUGUAY & 12 \\
\hline JAMAICA & 11 & VENEZUELA & 12 \\
\hline JAPAN & 12 & VIETNAM & 7 \\
\hline JORDAN & 12 & YEMEN & 5 \\
\hline
\end{tabular}


Figure A1: Change in the Elasticity of Trade with Respect to Air and Sea Distances (Country-Year Fixed Effects and Bilateral Controls)

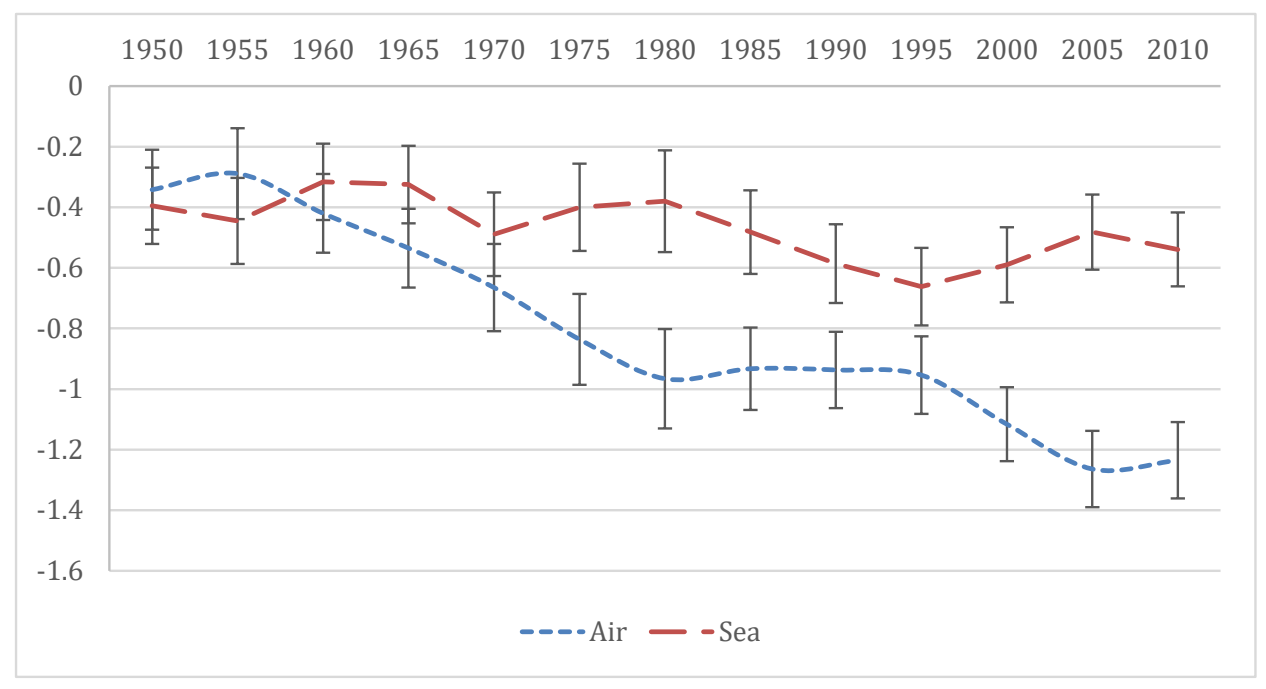

Notes: Estimated coefficients in specification (3) (also reported in column 2 of Table A2). Error Bars are plus and minus two standard errors, clustered at the country-pair and year level. 